Article

\title{
Welfare Impact of Globalization in Developing Countries: Examining the Mediating Role of Human Capital
}

\author{
Kehinde Oluseyi Olagunju 1,*(1), Adebayo Isaiah Ogunniyi ${ }^{2}$, Kunle Francis Oguntegbe ${ }^{3}$, \\ Ibrahim Oluwole Raji ${ }^{4}$ and Kolawole Ogundari ${ }^{5}$ \\ 1 Agricultural and Food Economics Branch, Agri-food and Biosciences Institute, 18a Newforge Lane, \\ Belfast BT9 5PX, UK \\ 2 International Food Policy Research Institute (IFPRI), Off Oro-Ago Crescent Garki II, Abuja 901101, Nigeria \\ 3 Department of Economics, Management, Institutions, University of Naples “Federico II", Monte \\ Sant'Angelo, 80126 Napoli, Italy \\ 4 School of Industrial Engineering, Università Carlo Cattaneo-LIUC, Corso G. Matteotti 22, \\ 21053 Castellanza, Italy \\ 5 Institute for Justice Research and Development, Florida State University, Tallahassee, FL 32306, USA \\ * Correspondence: olagunjukehindeoluseyi@gmail.com
}

Received: 10 June 2019; Accepted: 16 August 2019; Published: 21 August 2019

\begin{abstract}
Despite remarkable progress in the fight against poverty during the past few decades, the proportion of the poor living in developing countries is still on the high side. Many countries have promoted integration as an important development strategy; however, its impact on welfare of the poor is still unclear. In this study, we examine the roles of education and health dimensions of human capital in globalization and its impact on the poverty gap and the child mortality rate using cross-country panel data covering 110 developing countries between 1970 and 2015. We use a model based on system generalized method of moments (SGMM) to control for unobserved heterogeneity and potential endogeneity of the explanatory variables. The empirical results reveal that globalization reduces poverty gap and child mortality rate, and that an increase in the stock of human capital in developing economies improves welfare outcomes. The study also finds that human capital strengthens the negative impact of globalization on poverty gap and child mortality rate. For example, should enrollment in secondary school in Nigeria (in 2013) be increased from 39.2\% to $61.6 \%$, on average, it could translate into 2508 fewer under-five child deaths. We recommend that interconnectedness and promotion of human capital development should constitute a fundamental component of policy mix targeted at enhancing reduction of poverty and child mortality rate in developing countries.
\end{abstract}

Keywords: developing countries; globalization; human capital; wellbeing

JEL Classification: D60; F63; I31; O15

\section{Introduction}

Despite remarkable progress in the global fight against impoverishment in the last decades, the proportion of the world population living in extreme poverty remains inadmissibly high. As indicated by the World Bank, with more than 700 million people living on $\$ 1.90$ or less a day, and more than 300 million people living on less than $\$ 2.50$ a day in 2015 , the reduction of poverty remains a foremost global concern (World Bank 2017). The depths of poverty in developing countries are far higher than in their developed counterparts; for instance, more than half of the extreme world 
poor live in Sub-Saharan Africa (SSA) (World Bank 2017). The consequences of the poor state of wellbeing pose a threat for human development, increased productivity, social peace, political stability, and consequently overall economic development (Ogunniyi et al. 2016; Upton et al. 2016). Accordingly, the World Bank (2017) stresses the need to place the fight against poverty in all its dimensions as a top priority agenda in the developing countries' socio-political and economic research and development plans and programs.

Many countries-including both those developing and those developed-have promoted integration and openness as part of their reforms in the last three decades with the central aim of promoting economic growth and improving welfare outcomes. While some countries have reaped the benefits of globalization, many others, especially the developing countries, seem not to have gained as expected. The debate about the ambiguity of the benefits of globalization has been well discussed from both theoretical and empirical stand points. According to the Stolper-Samuelson trade theorem of the Heckscher-Ohlin $(\mathrm{H}-\mathrm{O})$, globalization is associated with reduction of inequalities in developing countries and also affords the least educated workers opportunities to the benefits of globalization (Kremer and Maskin 2003; Le Goff and Singh 2014). These predicted gains from globalization at the country level may come through plausible mechanisms such as cross-border flow of information, knowledge, ideas, technology, and openness to international trade, resulting in productivity improvements, investments in innovations, specialization, and efficient allocation of resources (Le Goff and Singh 2014; Perkins and Neumayer 2005). Similarly, a considerable body of empirical literature has established the welfare gains from globalization. Tayebi and Ohadi (2009), Bechtel (2014), Bergh and Nilsson (2014), and Ha and Cain (2017) found that integration into global economies leads to increase in income per capita, thereby reducing poverty gap and poverty headcount in developing countries. A similar study by Calderón and Chong (2001) established that export orientation ("openness") towards secondary activities may be associated with lower income inequality in developed countries. However, empirical findings are yet to converge on the positive impact of globalization, and it appears that globalization could be more detrimental to developing countries, evidenced in the recent economic and social crisis in East Asia and Latin America. For example, Kanbur (2000), Gaston and Rajaguru (2009), and Bergh and Nilsson (2014) concluded in their studies that globalization in all its dimensions only widens the gap that exists between the high and the low income groups in developing countries, implying that the opportunities from globalization may not be evenly distributed among citizens of these countries. In the same vein, two notable cross-country studies on developing countries conducted by Kremer and Maskin (2003) and Calderón and Chong (2001) argued that trade liberalization is positively related with increased inequality and does not benefit developing economies, which comprise mainly poor income countries. From the foregoing, the divide on the direction of the welfare impact of globalization in the developing countries leaves the debate much less unclear and open.

The stock of human capital in terms of education and health in a country has been perceived to be an important determinant of welfare, productivity, and economic growth in the world's poorest countries (Huay and Bani 2018; Ogundari and Awokuse 2018). Two notable empirical studies argue that increasing access to education is, on average, associated with more equitable earnings distribution (Neal and Johnson 1996; O'Neill 1990). Similarly, Huay and Bani (2018) found that increasing stock of knowledge helps reduce the poverty headcount, gap, and depth in developing countries. Using Sub-Sahara Africa as a case study, Le Goff and Singh (2014) showed that $10 \%$ increase in primary school completion rate could reduce poverty headcount and poverty gap by $2.8 \%$ and $3.5 \%$, respectively. Bloom et al. (2004), Ogundari and Abdulai (2014), and Ogundari and Awokuse (2018) also argued that populations that are healthier and better educated are likely to be more productive and could stimulate higher income per capita and improved welfare. In a study conducted by Mayer (2001), improved national health systems in eighteen Latin American countries were found to significantly lead to a reduction in the number of days lost to illness, incapacity, and weakness, thereby enhancing workforce productivity, turnover, and wages. 
The ambiguity and the complexity of the globalization-welfare relationship are apparent in literature, which seems to be changing over time. Certain human capital features are likely to have a place for globalization to have beneficial impacts on welfare in developing countries (Le Goff and Singh 2014). For example, the welfare improvement of globalization may be easily manifested in countries with high quality educational systems. Recent literature suggests a mutual relationship between economic globalization, human capital, and welfare outcomes (Ha and Cain 2017; Le Goff and Singh 2014). Despite these relevant considerations, most of the existing studies focused attention only on the one-to-one relationships between globalization and welfare as well as between human capital and welfare, with little or no crossovers (Bergh and Nilsson 2014). We are not aware of any previous studies that have examined the role of human capital on the effect of globalization on welfare, and therefore we attempt to remedy this lacuna in literature by testing whether the effects of globalization on welfare (measured by poverty gap and child mortality rate) changes with stock of human capital proxied by education and health in developing countries. The contributions of our study are three-fold. First, our study adds to the existing studies thus far on the impact of globalization on welfare of the poor but with a wider coverage. We take advantage of the World Bank's categorization of countries of the world based on the gross national income per capita into different income groups and extend our cross-country analysis to cover 110 developing countries. Second, to the best of our knowledge, we are the first to provide an analysis of the role of human capital in the relationship between globalization and poverty in developing countries. This is of importance for poor countries regarding how they can take advantage of the opportunities surrounding globalization in order to improve the welfare and the overall quality of life of their citizens. Lastly, unlike previous studies, we disentangle the dimensions of globalization (economic, social, and political) that contribute to the overall globalization-welfare relationship. To achieve the objectives of the study, we employ a model based on the system generalized methods of moments (SGMM) and analyze panel data covering 110 developing countries over an extended period from 1970 to 2015. In doing so, we examine the relationship between globalization, human capital, and welfare. We employ the KOF index of globalization as the measure of globalization level, and our welfare indicators are national poverty gap and child mortality rate. To measure the education dimension of human capital, we use primary, secondary, and tertiary school enrollment rates, and government expenditure on health as a percentage of gross domestic product (GDP) is used as a proxy for the health dimension of human capital. Our results suggest that globalization leads to reduction of poverty gap and child mortality rate in developing countries. We also find that human capital strengthens the negative impact of globalization on poverty gap and child mortality rate. Finally, contrary to expectations, we show that the poverty gap and the child mortality rate reduction effects of overall globalization are significantly driven only by its political and its social dimensions.

The rest of the paper is presented as follows. Section 2 outlines the relationship between globalization, human capital, and welfare. Section 3 presents the empirical analysis followed by the description of the data in the fourth section. Section 5 presents the empirical results and discussion. Finally, the conclusion and policy implications of the study are presented in the sixth section of the paper.

\section{Globalization, Human Capital, and Welfare Nexus}

There is no widely recognized definition of globalization, but it is typically taken to refer to the "increasing integration of societies in terms of economic, social, and political factors" (Bourguignon 2002), and the process through which it occurs is clearly multidimensional in nature (Arribas et al. 2009). The welfare impact of globalization has become a fiercely debated issue by social scientists and economists in recent years. The standard trade theory as set out by the Heckscher-Ohlin model expects that globalization reduces depth, gap, and severity of poverty in developing countries. A great deal of relevant literature also argues that globalization is "good" for the poor (Dollar and Kraay 2004; Dollar et al. 2013; Lundberg and Squire 2003). These studies argue that when developing countries become more integrated into the world economy, the process 
tends to foster specialization, competition, and incentives for stability in macroeconomic policies, thereby accelerating economic growth and consequently reducing poverty (Agénor 2002; Dollar 2001). For instance, in the study carried out by Dollar and Kraay (2004), trade volume was found to be positively associated with growth rate and higher income for the poor, and a similar study by Sapkota (2011) suggests that gains from integration and openness lead to improvements in quality of life of the poor in developing countries. Likewise, Ogundari and Ito (2015) found evidence of positive and significant effects of globalization defined by trade openness on growth of nutrient intake in SSA. Other welfare and production impacts of globalization include: increase in returns to higher education in poor countries (Stark 2004); transmission of health technology for health improvements for the poor (Deaton 2004; Papageorgiou et al. 2007); less social spending (Sinn 1997); enhancement of the structural transformation through urbanization (Godfrey and Julien 2005).

Although the positive effects of globalization are well established in literature, there are also plausible notions that suggest poverty-inducing effects of openness and integration, especially on the poor. For example, social globalization tends to contribute to wider spread of communicable diseases [e.g., Ebola virus disease, human immunodeficiency virus (HIV)], which may be detrimental to quality of life through lower labor productivity and supply of labor. This adverse effect is particularly more harmful to the developing countries where there is a lack of functioning health structures to tackle the potential outbreak of these diseases (Wamala and Kawachi 2007). However, concerted efforts via international cooperation on global health issues could help foster improved health and welfare in developing countries (Dollar 2001). In the same line of argument, Yach et al. (2007) and Mendez and Popkin (2004) proposed that social integration in the form of social norms and lifestyle patterns, which include unhealthy smoking and eating habits, may have damaging impacts on productivity and health. Another poverty inducing effect of globalization includes making capital cheaper and more available, which would result in readily substitution of labor with capital, and many laborers would have to be laid off in the short run, consequently leading to loss of livelihood of many (Agénor 2002). Bhagwati and Srinivasan (2002) established that trade openness is significantly associated with greater commitment to low inflation, resulting in higher unemployment in the short run.

At the macro level, the concept of human capital is often defined as the stock of knowledge, skills, competencies, and attributes that facilitate the creation of personal, social, and economic well-being (Brian 2007). Education and health statuses are the most common human capital measures (Ogundari and Awokuse 2018). The quality and the stock of human capital affect how well resources are allocated in a society and thereby the possibilities for different households to boost production and perhaps increase spending on household consumption, which may improve their welfare. The combination of a well-educated and healthier workforce could increase the capacity to take advantage of innovation opportunities from globalization and consequently increase productivity and overall wages (Le Goff and Singh 2014; Ogundari and Abdulai 2014). Early studies by Barro and Lee (1994) and Rosenzweig (1988) concluded that countries with high ratios of investment on health to GDP had higher income per capita (a welfare measure). Hanushek and Woessmann (2008) analyzed the impact of cognitive skills on improving economic wellbeing. They found that cognitive skills of the population are strongly associated with the level of individual earnings, income distribution, and overall growth of the economy, which have concomitant effects on national poverty headcount reduction in developing economies. Using a panel of 100 countries observed from 1960 to 1995, Barro (2013) found that average years of school attainment at the secondary level is positive and strongly related to economic growth. The study concluded that educational background of labor force plays a complementary role in the diffusion and the adoption of technology in the development process. The importance of education is further supported by Glewwe et al. (2014) and Le Goff and Singh (2014). Glewwe et al. (2014) found that economic growth is lower in SSA than in other countries of the world, while Le Goff and Singh (2014) found that poverty incidence in terms of headcount, gap, and severity are higher in SSA than in other countries of the world. Both studies attributed their findings to low quality of schools and low investment in education in the continent. 
Having established that globalization and human capital (especially in terms of education and health) independently influence welfare outcomes, the associated positive or negative impacts of globalization on welfare may be influenced by human capital. In particular, human capital may mediate the extent to which welfare gains from globalization are distributed across different groups in society. According to Newfarmer and Sztajerowska (2012), the opportunities from economic globalization, such as potential income and employment gains, are not automatic, and such gains can only materialize by providing framework for improving the stock of human capital in the country. They asserted that technology transfers from globalization, which can enhance income per capita, may be made redundant if the level of skills available within the country is not sufficient enough to absorb and properly put to use such technologies. Similarly, Borensztein et al. (1998) examined the impact of economic dimension of globalization on welfare in developing countries. They found that improvement in welfare as a result of economic globalization (proxied by the proportion of products produced by foreign organizations in the total number of products) is conditional on the level of education human capital in the host country. Chang et al. (2009) found that the welfare effects of trade openness may be significantly improved when the investment in human capital is stronger. Gu and Dong (2011) emphasized that the harmful or the useful impacts of financial globalization heavily depend on the level of financial education in the country. They asserted that, without substantial improvement in the quality of education and financial systems in developing countries, the expected benefits of globalization may not be realized. Stark (2004) found that the social dimension of globalization in terms of information flow (e.g., the use of internet) may have negative impacts on child wellbeing in the absence of quality education. For example, several child health related issues have been reported in Nigeria as a result of improper use of vaccines and drugs obtained via internet sources without due attention to proper orientation and education on drug use (Ophori et al. 2014).

In the studies of Deaton (2004) and Papageorgiou et al. (2007), they found that globalization affords developing countries the opportunities of transmission of health technologies for health and welfare improvement. However, this may not be able generate the expected positive outcomes if the national health systems (health capital) are not developed enough to effectively take advantage of these technologies. Furthermore, one of the manifestations of globalization is the increasing urbanization rate in developing countries, which may have both positive and negative effects on welfare. According to Welander et al. (2015), effective national health care systems must be in place for the increasing rate of urbanization to have beneficial effects in developing counties. Similarly, Mayer (2001) argued that good health capital must be in place for globalization to have beneficial impacts on welfare of the poor. It is widely agreed upon that economic globalization is key for the transfer of technology for improved workforce productivity; however, in the absence of quality health capital (for example, good national health care services), globalization may not be able to create welfare improvement opportunities for citizens who have poor health due to loss in work hours, incapacity, and reduction in workers' physical and mental capacities. In line with this argument, Bloom et al. (2004), Ogundari and Abdulai (2014), and Ogundari and Awokuse (2018) argued that citizens who are healthier are more likely to have the mental capacities to absorb technical innovations and put them to use than less healthy citizens, suggesting that health capital plays an important role in the potential effects of globalization on productivity of workers, which has strong implications for their welfare.

\section{Empirical Specification and Estimation}

To examine the impact of globalization and human capital on welfare in developing countries, we start by specifying a baseline panel model following the globalization-poverty frameworks suggested by Ha and Cain (2017), Bergh and Nilsson (2014) and Welander et al. (2015) defined below:

$$
P_{i t}=\theta+\beta_{1} O G I_{i t-1}+\beta_{2} H C_{i t-1}+\delta_{i}+\mu_{t}+\varepsilon_{i t},
$$


where the subscripts $i$ and $t$ represent the country and the time periods, respectively, $P_{i t}$ denotes welfare measures represented by the national poverty gap (a direct poverty measure) and the child mortality rate (indirect poverty measure). $O G I_{i t-1}$ is the one year lagged overall globalization index, $H C_{i t-1}$ denotes one year lagged human capital measures, $\delta_{i}$ represents country specific effects such as country characteristics that do not change over time, $\mu_{t}$ is the time specific effect that controls for shocks that do not vary among countries such as global demand shocks, and $\varepsilon_{i t}$ is the error term. $\theta, \beta_{1}$ and $\beta_{2}$ are the estimated parameters.

To effectively identify the effect of globalization and human capital on welfare, we include a set of control variables, $C V_{i t}$, into Equation (1). $C V_{i t}$ represents control variables capable of explaining $P_{i t}$, which are included to avoid omitted variable bias problems. The choice of $C V_{i t}$ is guided by economic reasoning and previous similar empirical studies (Ha and Cain 2017; Le Goff and Singh 2014; Welander et al. 2015).

$$
P_{i t}=\theta+\beta_{1} O G I_{i t-1}+\beta_{2} H C_{i t-1}+\beta_{3} C V_{i t}+\delta_{i}+\mu_{t}+\varepsilon_{i t},
$$

$\beta_{3}$ is the coefficient of the estimated parameter of $C V_{i t}$. In order to introduce the role of human capital in the globalization-welfare relationship, we follow Chang et al. (2009) and Le Goff and Singh (2014) by adding interaction terms. This is done to allow the welfare-globalization relationship to change with education and health measures of human capital. We therefore augment Equation (2) by including the interaction terms.

$$
P_{i t}=\theta+\beta_{1} O G I_{i t-1}+\beta_{2} H C_{i t-1}+\beta_{3} C V_{i t}+\beta_{4} G I_{i t-1} \times H C_{i t-1}+\delta_{i}+\mu_{t}+\varepsilon_{i t},
$$

With the understanding that globalization has three main dimensions, we run additional regressions where we replace the overall globalization index with its three dimensions (economic, social, and political globalization). The central purpose of these additional regressions is to have a more precise understanding of the relative contribution of the components of the globalization process that explain the globalization-human capital-welfare relationship. Similar analyses were conducted by (Bergh and Nilsson 2014) and Welander et al. (2015).

The estimations of Equations (1)-(3) are complicated by the existence of confounding factors (Bergh and Nilsson 2014). It is possible that there are unobserved country-, system-, and time-specific factors that impact welfare that are also related to the country's level of globalization and human capital. Also, estimation of these equations poses a challenge of potential endogeneity that may result from reverse causation. An attempt not to consider these estimation issues would yield inconsistent estimates. To control for unobserved country-specific effects, potential endogeneity issues, and collinearity of regressors, we employ the system generalized methods of moments (SGMM) estimator developed by Blundell and Bond (1998). This estimation technique makes an exogeneity assumption where any correlations between endogenous variables and unobserved fixed effects are constant over time, allowing the inclusion of level equations in the system and the use of lagged differences as instruments for the levels. The SGMM is also able to overcome the econometric problems of cross-sectional dependence of countries and multi-correlation that are prevalent in macro panel models (Arellano and Bond 1991).

It is imperative to verify the consistency of the SGMM estimator. To do this, we have to ascertain that lagged values of the regressors are valid instruments. We examine this issue by considering the Hansen test of over-identifying restrictions. The no rejection of the null hypothesis implies that instrumental variables are not correlated with the residual and are satisfying the orthogonality conditions required. A serial correlation test is also carried out and demonstrates that the errors exhibit no second-order serial correlation. 


\section{Data}

We employ an unbalanced panel dataset covering 110 low- and middle-income countries from which there are available data between 1970 and 2015 (Table A1 contains the list of sample countries) ${ }^{1}$. The selection of the 110 countries is guided by the World Bank's categorization of countries of the world by gross national income (GNI) per capita (World Bank 2016) ${ }^{2}$. Data used in the study are taken mainly from the World Development Indicators (hereafter, WDI) dataset (World Bank 2016) and the KOF globalization index dataset (Dreher et al. 2008).

\subsection{Dependent Variables: National Poverty Gap and Child Mortality Rate}

The complexity of welfare as a concept makes it difficult to measure (Ravallion 2001). As highlighted by Ravallion (2003), early studies on the globalization-welfare nexus focused on income inequality, which is fundamentally a relative measure of welfare. Inequality does not give an absolute picture of wellbeing, and therefore it may be misleading to capture wellbeing with income inequality (Ha and Cain 2017). Another commonly used proxy for welfare is the poverty headcount, an absolute measure defined as the percentage of the population whose income or consumption is below the minimum threshold (poverty line). According to Cowell et al. (1998), the poverty line is a threshold income above which a family can provide a minimum nutrition level and other necessities. The poverty line was operationalized by the World Bank in 2015 using price data from the world's fifteen poorest countries. The threshold was set at $\$ 1.90$ per person per day using a purchase power parity (PPP) approach to normalize differences across countries in terms of currency exchange rates and the cost of living (World Bank 2016). The use of poverty headcount as a poverty measure has been well employed in past studies (Bergh and Nilsson 2014; Le Goff and Singh 2014), albeit it creates challenges for research that cuts across countries (Ha and Cain 2017).

The present study is a cross-country research, and therefore we follow Ha and Cain (2017) by adopting national poverty gap statistics sourced from WDI. The poverty gap measures both the depth and the extent of poverty in a country, operationalized by estimating the total shortfall in income between all poor people and the poverty line divided by the size of the nation's population. As poverty gap is normalized by the PPP, it is appropriate for analyses that involve cross national comparisons because it is normalized by the PPP. However, its usefulness is dependent on robust and accurate national assessments of poverty.

An alternative indirect indicator of welfare and poverty is child mortality rate sourced from WDI, defined as the number of children dying before reaching five years of age per 1000 live births. This measure has been used in previous relevant studies to compensate the downsides of poverty gaps (Gerring et al. 2012; Ha and Cain 2017; McGuire 2006). The actual quality of life of the population living in a poor society is reflected in the child mortality recorded, as it captures the number of children and infants that survive childhood and grow to become adults (Ghobarah et al. 2004; McGuire 2006; Stasavage 2005). The data on child mortality rate (indirect measure) are sufficiently available for more years and countries compared to poverty gap (direct measure).

\subsection{Main Independent Variables: Globalization and Human Capital}

To measure globalization, we use the KOF globalization index developed by Dreher et al. (2008), which covers three dimensions-economic, social, and political globalization-all given equal weights using a principal components analysis. The index takes values between 0 and 100, with higher values

1 For the regression with poverty gap as the dependent variable, we are able to use of 34 countries out of the 110 countries for the estimation. This is due to missing poverty gap data for most of the countries. We use the entire 110 countries for analysis with child mortality as the dependent variable.

2 Low income economies are countries with GNI per capita of $\$ 995$ or below in 2015 , while middle income economies, which include lower and upper middle income, are those with GNI capita lying between \$996 and \$12,055. 
indicating more globalization, and has the advantage of being comparable between countries and over time from 1970 and onwards, making it suitable for a cross-national research (Bergh and Nilsson 2014). In our studies, we take advantage of the ability of the index to be disaggregated into different components. In addition to the use of overall globalization index (OGI, hereafter) for our analysis, we further explore its components-economic globalization index (EGI), social globalization index (SGI), and political globalization index (PGI) - which enhance our understanding of the globalization-human capital-poverty relationship. Table A2 in the Appendix A contains details of the components of the index. To the best of our knowledge, only Bergh and Nilsson (2014) employed this index in examining the globalization-poverty nexus. As shown in Figure 1, both child mortality and national poverty gap are negatively correlated with aggregate globalization. Bergh and Nilsson (2014) reported a similar relationship.

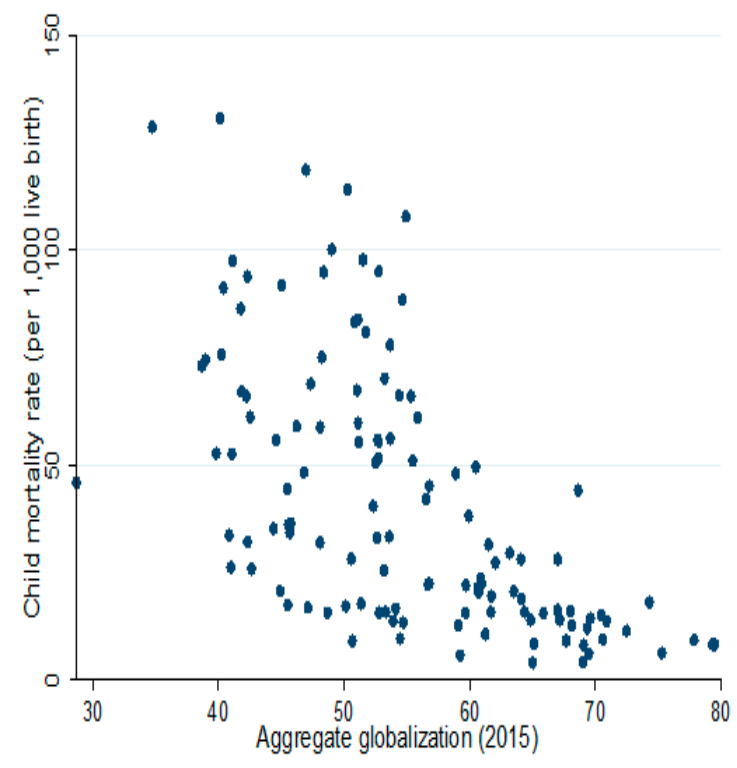

(a)

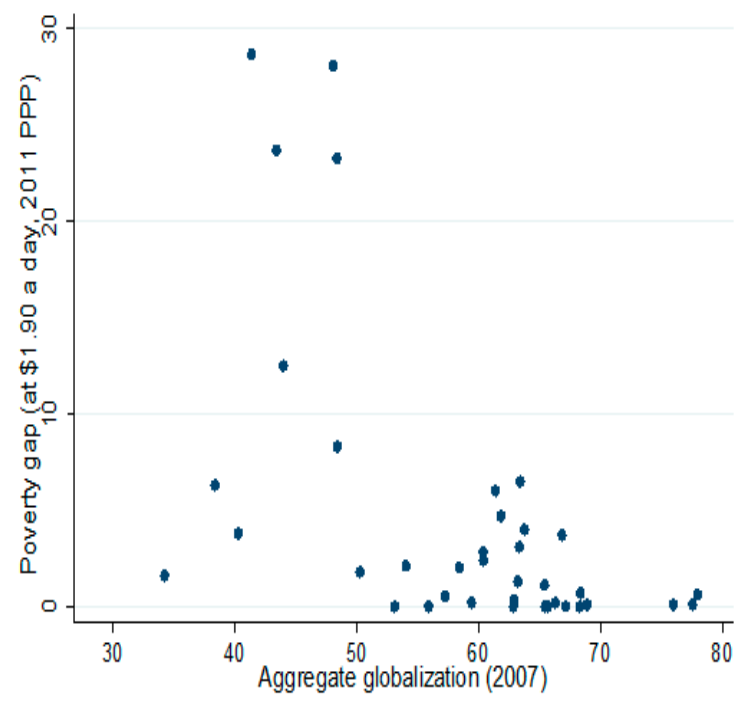

(b)

Figure 1. (a) Aggregate globalization and child mortality rate (2015) and (b) aggregate globalization and poverty gap (2007). Source: World Bank (2016) and Dreher et al. (2008).

Human capital, defined as the productive capacity of labor, is mainly determined and represented by stock of knowledge (education) and health (Ogundari and Awokuse 2018; Young et al. 2004). To capture education human capital, although there is not yet unanimity on what defines this dimension of human capital, we employ different measures of education to provide opportunities for cross-comparison among the indicators, as noted by Ogundari and Awokuse 2018. To this end, we use education enrollment at primary, secondary, and tertiary school levels as proxies for the education dimension of human capital in our analysis. With regards to the health dimension of human capital, we use government expenditure on health as a proxy for health capital, similar to the studies of Ogundari and Awokuse (2018) and Azizi (2018). This is in line with the reasoning that government expenditure on health is closely associated with better health status and health systems in a country (Murray and Lopez 1997). Although many other studies have used different measures of health human capital, such as adult survival rate or calorie intake per capita (see Acemoglu and Johnson 2007; Bloom et al. 2013; Hartwig 2010), we choose to use government expenditure on health as the only measure due to its availability and the absence of data on other potential proxies. 


\subsection{Control Variables}

To estimate the impacts of globalization and human capital on welfare in developing countries, we consider a set of control variables, which are included to prevent omitted variable bias in the specification. The variables are sourced from the WDI dataset. The selection of these variables is based on economic reasoning and relevant literature. First, to account for the level of economic growth and economic resources available to a nation, we include GDP per capita. A positive effect of the level of GDP per capita is expected, as it increases the resources available to catering for basic needs of life. Several studies have found that improved level of national economic wealth significantly reduces poverty level (Ha and Cain 2017; Olagunju et al. 2015). The relevance of agriculture is accounted for with the inclusion of rural population share, defined as the share of total population living in the rural areas (FAO 2013). In most developing countries, agriculture is mainly practiced in rural regions. Due to resource constraints that characterize the rural population, it is expected for the rural population share to be positively associated with poverty gap and child mortality rate. High child mortality rate is prevalent in rural areas (Ashagidigbi et al. 2018; Olagunju et al. 2018). Similarly, we include arable land area, a proxy of agricultural production level, to account for the resource endowments of the countries. There is a wide difference in the land resources available across the world, which determines the level of agricultural production, especially in developing countries. Closing this variation is perceived as a way to scale poverty (Ogunniyi et al. 2017). Similar to Dithmer and Abdulai (2017) and Ha and Cain (2017), we include economic growth (growth rate of GDP per capita sourced from WDI) to account for growth in cyclical fluctuation in aggregate output. An increase in economic growth is expected to result in an increase in aggregated production and consumption of goods and services (including food and non-food items). Economic growth is generally recognized as an important determinant of food poverty (Ames et al. 2001). To account for demographic structure of the countries understudied, we include annual population growth, which controls for the population pressure on available economic resources. Population growth is expected to be positively associated with poverty and child mortality because a fast growing national population implies an increase in government's public service burden, therefore reducing the effect of social welfare spending. Similarly, increasing population growth leads to an increase in the demand for food for the whole population and could reduce per capita food availability (Dithmer and Abdulai 2017; Ogunniyi et al. 2018a).

We account for the significance of infrastructural development as a determinant of welfare outcomes and thereby include access to electricity, measured as the percentage of the population with access to electricity. Access to infrastructure and improved technologies can help agri-food, manufacturing, and processing industries boost aggregate productivity in developing countries, thereby improving livelihood of the population (Alaverdyan et al. 2015; Ogunniyi et al. 2018b; Olagunju and Ogunniyi 2015).

Finally, with the understanding of the importance of the quality of macroeconomic policy in enhancing welfare, we use the consumer price index (CPI) inflation rate to control for national monetary policy in our model. According to Loayza et al. (2012), high inflation is positively associated with ill macroeconomic policies. Unstable macroeconomic policies proxied by high inflation rate have been found to increase poverty gap, headcount, and child mortality in developing countries (Ha and Cain 2017; Le Goff and Singh 2014). The descriptive statistics of all the variables employed in the model estimation are presented in Table 1. 
Table 1. Descriptive statistics.

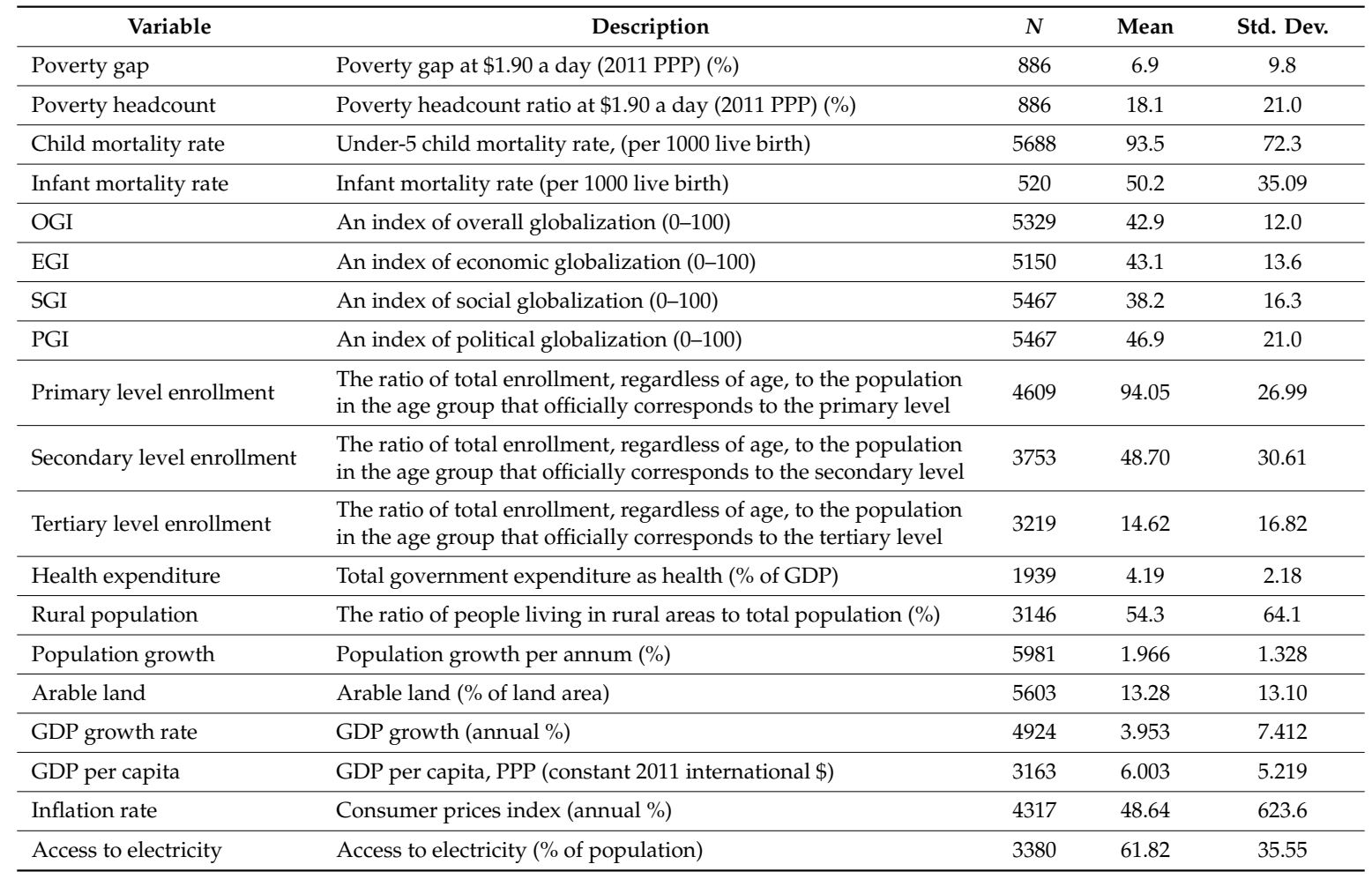

Note: OGI: overall globalization index; EGI: economic globalization index; SGI: social globalization index; PGI: political globalization index; GDP: gross domestic product; PPP: purchase power parity.

\section{Empirical Results}

\subsection{Correlation Matrix of the Explanatory Variables}

In Table A3 in the Appendix A, we report the correlation analysis between the explanatory variables considered in the regression models. The correlation analysis provides a snapshot of the degree of bivariate association between variables (Self and Grabowski 2004). The results reveal that most of variables are not strongly correlated, suggesting that multicollinearity should not be a problem for our estimations.

\subsection{Diagnotics Test Results}

Following the standard practice, the consistency of the estimated parameters of our models is based on the diagnostic test results from the estimated SGMM indicated by presence of first-order autocorrelation [AR (1)] and the absence of second-order autocorrelation [AR (2)] in the residuals of the model. These are reported at the lower part of the tables. As anticipated, for all our models, we reject the null hypothesis of no first-order residual serial correlation but accept the hypothesis of no second order serial correlation for the models. The Hansen test fails to reject the hypothesis of jointly valid instruments for all the models. The Hansen test statistic of overidentifying restrictions is insignificant, which suggests that the set of instruments employed fulfills the exogeneity condition required to obtained consistent estimates in all the models.

\subsection{The Effect of Overall Globalization and Human Capital on National Poverty Gap}

First, we examine the extent to which OGI and human capital affect poverty gap using the regression model given in Equations (1) and (2) and subsequently the joint impact of OGI and human capital on poverty gap, as in Equation (3). Specifically, Table 2 presents the empirical results for the three regression specifications estimated with the national poverty gap (\$1.90 per day) as the dependent 
variable. Model (1) is the base model. Model (2) adds all the control variables. Model (3) includes the controls and the interaction term between OGI and education human capital measures (primary enrollment, secondary enrollment, tertiary enrollment). Finally, model (4) reports the results with the interaction term between OGI and health dimension of human capital measure (health expenditure).

Table 2. Estimation results, the effects of overall globalization and human capital on poverty gap at \$1.90 per day (PPP), 1970 and 2015.

\begin{tabular}{|c|c|c|c|c|}
\hline Dependent Variable: Poverty Gap & (1) & (2) & (3) & (4) \\
\hline OGI & $\begin{array}{c}-0.184^{* * *} \\
(0.069)\end{array}$ & $\begin{array}{c}-0.176^{* *} \\
(0.034)\end{array}$ & $\begin{array}{c}-0.944^{* * *} \\
(0.295)\end{array}$ & $\begin{array}{c}-0.281 * * * \\
(0.060)\end{array}$ \\
\hline Primary enrollment & $\begin{array}{l}-0.046 \\
(0.052)\end{array}$ & $\begin{array}{c}-0.154 \text { ** } \\
(0.064)\end{array}$ & $\begin{array}{c}-0.263^{* *} \\
(0.118)\end{array}$ & $\begin{array}{c}-0.059 * * \\
(0.030)\end{array}$ \\
\hline Secondary enrollment & $\begin{array}{c}-0.086^{* * *} \\
(0.026)\end{array}$ & $\begin{array}{c}-0.164^{* * *} \\
(0.045)\end{array}$ & $\begin{array}{l}-0.043 \\
(0.176)\end{array}$ & $\begin{array}{c}-0.070 * * * \\
(0.026)\end{array}$ \\
\hline Tertiary enrollment & $\begin{array}{c}-0.069^{* * *} \\
(0.027)\end{array}$ & $\begin{array}{l}-0.104 \\
(0.046)\end{array}$ & $\begin{array}{c}-0.325^{* *} \\
(0.142)\end{array}$ & $\begin{array}{c}-0.056^{* * * *} \\
(0.02)\end{array}$ \\
\hline Health expenditure & $\begin{array}{c}-0.700 * \\
(0.353)\end{array}$ & $\begin{array}{c}0.361 \\
(0.265)\end{array}$ & $\begin{array}{l}-0.113 \\
(0.170)\end{array}$ & $\begin{array}{c}-1.620^{* * *} \\
(0.382)\end{array}$ \\
\hline Rural population & & $\begin{array}{c}0.412 * * * \\
(0.105)\end{array}$ & $\begin{array}{c}1.240 \\
(0.9734)\end{array}$ & $\begin{array}{l}1.864 * \\
(1.059)\end{array}$ \\
\hline Population growth & & $\begin{array}{c}-0.5222^{* *} \\
(0.157)\end{array}$ & $\begin{array}{l}-0.032 \\
(0.577)\end{array}$ & $\begin{array}{l}-0.262 \\
(0.538)\end{array}$ \\
\hline Arable land & & $\begin{array}{l}-0.282 \\
(0.413)\end{array}$ & $\begin{array}{l}-0.217 \\
(0.357)\end{array}$ & $\begin{array}{l}-0.262 \\
(0.411)\end{array}$ \\
\hline GDP growth & & $\begin{array}{c}-0.097^{* *} \\
(0.049)\end{array}$ & $\begin{array}{l}-0.059 \\
(0.054)\end{array}$ & $\begin{array}{l}-0.057 \\
(0.053)\end{array}$ \\
\hline GDP per capita & & $\begin{array}{c}0.140 * * * \\
(0.033)\end{array}$ & $\begin{array}{c}-0.123 \text { **** } \\
(0.034)\end{array}$ & $\begin{array}{c}-0.506 \text { * } \\
(0.282)\end{array}$ \\
\hline Inflation rate & & $\begin{array}{c}0.234^{* * *} \\
(0.064)\end{array}$ & $\begin{array}{c}0.003 \\
(0.002)\end{array}$ & $\begin{array}{c}0.006^{* * *} \\
(0.002)\end{array}$ \\
\hline Access to electricity & & $\begin{array}{l}-0.030 \\
(0.072)\end{array}$ & $\begin{array}{c}-0.106^{*} \\
(0.055)\end{array}$ & $\begin{array}{c}-0.126^{* * *} \\
(0.043)\end{array}$ \\
\hline OGI $\times$ Primary enrollment & & & $\begin{array}{c}-0.005^{* *} \\
(0.002)\end{array}$ & \\
\hline OGI $\times$ Secondary enrollment & & & $\begin{array}{c}-0.108^{* * * *} \\
(0.030)\end{array}$ & \\
\hline OGI $\times$ Tertiary enrollment & & & $\begin{array}{c}-0.116^{* * * *} \\
(0.007)\end{array}$ & \\
\hline OGI $\times$ Health expenditure & & & & $\begin{array}{c}-0.030 * * * \\
(0.008)\end{array}$ \\
\hline Constant & $\begin{array}{c}12.255^{* * *} \\
(4.278)\end{array}$ & $\begin{array}{c}58.987^{* * *} \\
(15.901)\end{array}$ & $\begin{array}{c}35.121 \text { *** } \\
(8.636)\end{array}$ & $\begin{array}{c}68.809 * * * \\
(21.999)\end{array}$ \\
\hline Observations & 454 & 454 & 454 & 454 \\
\hline Number of countries & 34 & 34 & 34 & 34 \\
\hline $\operatorname{AR}(1) p$-value & 0.025 & 0.011 & 0.001 & 0.021 \\
\hline $\operatorname{AR}(2) p$-value & 0.285 & 0.830 & 0.510 & 0.532 \\
\hline Hansen test $p$-value & 0.721 & 0.630 & 0.589 & 0.258 \\
\hline
\end{tabular}

Notes: (1) Robust standard errors in parentheses. ${ }^{* * *} p<0.01,{ }^{* *} p<0.05,{ }^{*} p<0.1$. (2) All the variables are in logarithmic forms.

With respect to the baseline model, model (1), and model (2), the results show that aggregate globalization (OGI), which includes all three dimensions of globalization, is significantly associated with reduction in poverty gap. Similar relationships and significances are reported across the remaining models. Accordingly, in model (2), an increase in the OGI by $10 \%$ would lead to the poverty gap being reduced by $1.7 \%$. As an example, had Mauritania remained in the same level of globalization as Georgia (in 2014), and assuming all other things had remained the same, it could have reduced its poverty gap by about $32 \%$, from $53 \%$ to $21 \%$. In practice, this could be accomplished, for example, through removal of trade restrictions and by enhancing information flow. The results lend support for the view that globalization contributes positively to developing countries' welfare (Bergh and Nilsson 2014; Dreher et al. 2008; Ha and Cain 2017; Welander et al. 2015). 
Meanwhile, the impact of primary, secondary, and tertiary school enrollment on poverty gap, as estimated in all the models, consistently reveals that education is negatively associated with poverty gap. In particular, estimates in model (2) suggest that a 10\% increase in primary, secondary, and tertiary school enrollment could reduce the poverty gap, which persists in developing countries by $1.5 \%$, $1.6 \%$, and $1.0 \%$, respectively. We only observe the significance of these relationships for primary and secondary school enrollment. The empirical findings confirm the productivity-enhancing significance of education as an important dimension of human capital capable of improving welfare, as reported in the works of Huay and Bani (2018) and Ogundari and Awokuse (2018). Similarly, our findings appear to support the hypothesis that the poverty reduction effect of education is determined by the country's level of economic development, and that developing countries derive more benefits from secondary and primary school education, while higher education contributes more in the developed countries (Petrakis and Stamatakis 2002).

The results of the inclusion of the interaction between OGI and the three measures of education human capital are reported in model (3). With the inclusion of the interaction terms, the coefficient of OGI still retains its negative sign and significance. The negative coefficient of OGI indicates a reduction in poverty gap as aggregate globalization increases. The interaction terms are negative and statistically significant for all the measures of education human capital, which reveal a complementary effect in which the education human capital strengthens the impact of aggregate globalization on poverty. In the same vein, we can also deduce that globalization effects in countries with more enrollment in primary school weakly reduce poverty gap. Developing countries that benefit more from globalization are those that have high enrollment in secondary and tertiary education. A possible explanation for this is that developing countries with high education human capital (which reflects an improved level of learning skills) are better able to explore and to take full benefits of globalization. The findings lend support to the results of Le Goff and Singh (2014).

Model (4) of Table 2 reports the results of the estimation for examining the impact of the health dimension of human capital in the aggregate globalization-poverty gap relationship. The negative coefficient of the interaction effect of OGI and health expenditure indicates that the beneficial effect of aggregate globalization on closing the poverty gap becomes larger when investment in health is stronger. Similarly, developing countries with high health human capital proxied by high government expenditure on health are associated with a reduction in poverty gap, suggesting that having good health structures and health systems is associated with better management of globalization effects on the poor. The results provide a plausible explanation for the welfare improvement impact of globalization, especially in countries with good health structures, lending a contrary argument to the proposition that globalization is associated with increasing poverty gap, as provided in the study of Wamala and Kawachi (2007). A possible explanation for this is that integration of developing countries could result in the spread of or the investment in global health management practices and vaccines, thereby improving the overall health sector, which may lead to reduction in poverty through higher labor productivity and labor supply.

Turning to the control variables, we observe uniformities in the signs of the coefficients of the control variables across models (2)-(4), albeit with different significance levels. As expected, the coefficients of rural populations are positive in all the models but significant only in model (3), suggesting that developing countries with high rural population share are poorer. For example, the poverty gap in Nigeria in 2009 (with 64\% living in rural areas) was ten times higher than that of Brazil, which only had 19\% rural population share. The results also reveal that high GDP per capita is associated with a reduction in poverty gap. The findings confirm the significance of general economic development in poverty reduction. In recent years, many of the low- and the middle-income countries have witnessed significant economic growth but were not still able to make significant improvements in closing the poverty gap and the headcount (World Bank 2016). The result is in line with the findings of Ha and Cain (2017) that reveal that GDP per capita significantly improves the welfare of the population living in developing countries. The results also show that arable land area has a negative, although 
not statistically significant, impact on poverty gap, lending support to the hypothesis that reducing production gap among producers in developing countries would contribute to welfare improvement. Based on the estimation in model (3), a 10\% increase in arable land area would reduce poverty gap by $2.6 \%$ on average. This is also consistent with the findings by Dithmer and Abdulai (2017).

Our empirical results also reveal that the coefficients of population growth and inflation are positively related with poverty gap, although not significantly so, indicating that a large poverty gap exists in developing countries characterized with high population growth and instability in macroeconomic policies. Dithmer and Abdulai (2017), Feleke et al. (2005), and Rena (2005) reported similar findings at global, national, and household levels, respectively. Lastly, access to electricity enters negatively into all the regressions, suggesting that developing economies that have access to infrastructural development could reduce the poverty gap. This is consistent with the households and the national level findings by Olagunju and Ogunniyi (2015).

\subsection{Exploring Disaggregated Globalization Index, Human Capital, and Poverty Gap}

In this subsection, we report the relationships between the three dimensions of globalization, human capital, and poverty gap. Specifically, Table 3 (A) reports that economic globalization index (EGI) is positively associated with poverty gap. In model (6), a 10\% increase in the EGI could significantly increase the poverty gap by $0.9 \%$. This result suggests that a higher level of economic integration in the world economy is associated with a wider poverty gap in developing countries. One likely explanation for this relationship is that, as countries open their economies, capital as a factor of production becomes more available, making firms that are labor-intensive (mostly common in developing countries) replace labor with capital in production, resulting in workers being laid-off and consequent increases in the poverty gap. Similarly, as workers are being laid-off, the level of unemployment increases, which may force some indigenous firms out of business (Bergh and Nilsson 2014). The coefficients of the interaction terms are all negative and statistically significant, which indicates a substitution effect whereby education weakens the adverse impact of economic globalization on poverty gap. In other words, the poverty enhancing effect of economic globalization could be upturned if education and health human capital development improve in developing countries. The findings are in line with the results of Le Goff and Singh (2014), who found that the detrimental impact of trade openness on poverty headcount in Sub-Saharan Africa reduces as the investment in education increases.

In addition, across all the models in Table 3 (B) and (C), we find that increases in social and political globalization are consistently associated with reduction in poverty gap, indicating that, should a country increase its level of information flow, participation in international treaties, international tourism, etc., it could result in a significant reduction in poverty gap. The findings confirm the significance of social and political integration in welfare improvement. Dimitriadis and Koh (2005) and Maurer (2013) argue that market performance depends largely on the information flow efficiency. Information asymmetry is typical in developing countries, causing high transaction costs and potential market inefficiency. Duncombe and Heeks (1999) and Elbers and Lanjouw (2001) show that access to rural telephony increases the prices farmers receive for their crops and the earnings from off-farm activities. As reported in models (7) and (8), the coefficients of the interaction terms are all negative and statistically significant, indicating complementary effects whereby education human capital strengthens the impact of social and political globalization in closing the poverty gap in developing countries. Overall, the results in Table 3 also reveal the component of aggregate globalization that explains the negative relationship with poverty gap in Table 2 . The results show that the negative coefficient of aggregate globalization comes from both the political and the social dimension rather than from the economic dimension. Our findings lend support to the study by Ha and Cain (2017), who found that the foreign direct investment (FDI), a major component of EGI, does not significantly contribute to reduction of poverty gap in developing countries. 
Table 3. Estimation results, the effects of disaggregated globalization index and human capital on poverty gap at $\$ 1.90$ per day (PPP), 1970 and 2015 .

\begin{tabular}{|c|c|c|c|c|}
\hline Dependent Variable: Poverty Gap & (5) & (6) & (7) & (8) \\
\hline \multicolumn{5}{|l|}{ (A) Economic globalization } \\
\hline EGI & $0.008(0.079)$ & $0.094 *(0.052)$ & $0.857^{* * *}(0.216)$ & $0.670^{* * *}(0.462)$ \\
\hline Primary enrollment & $-0.061(0.051)$ & $-0.159 * *(0.063)$ & $-0.429^{* * *}(0.123)$ & $-0.140^{* *}(0.055)$ \\
\hline Secondary enrollment & $-0.129^{* * *}(0.026)$ & $-0.063(0.049)$ & $-0.218(0.134)$ & $-0.026(0.045)$ \\
\hline Tertiary enrollment & $0.022(0.029)$ & $-0.057(0.048)$ & $0.216(0.151)$ & $-0.102 * *(0.041)$ \\
\hline Health expenditure & $-0.496^{* * *}(0.187)$ & $0.189(0.271)$ & $0.543 * *(0.235)$ & $-0.764^{* * *}(0.291)$ \\
\hline EGI $\times$ Primary enrollment & & & $0.007^{* * *}(0.002)$ & \\
\hline EGI $\times$ Secondary enrollment & & & $0.004 *(0.002)$ & \\
\hline EGI $\times$ Tertiary enrollment & & & $-0.009^{* * *}(0.003)$ & \\
\hline EGI $\times$ Health expenditure & & & & $-0.025^{* * *}(0.007)$ \\
\hline Constant & $24.442 * * *(8.064)$ & $14.791^{* * *}(6.438)$ & $13.514 *(4.821)$ & $15.140 * * *(9.708)$ \\
\hline Observations & 454 & 454 & 454 & 454 \\
\hline Number of countries & 34 & 34 & 34 & 34 \\
\hline \multicolumn{5}{|l|}{ (B) Political globalization } \\
\hline PGI & $-0.150^{* * *}(0.042)$ & $-0.081(0.071)$ & $-0.059(0.075)$ & $-0.048^{* *}(0.017)$ \\
\hline Primary enrollment & $-0.045(0.051)$ & $-0.153^{* *}(0.066)$ & $-0.133(0.137)$ & $-0.292(0.977)$ \\
\hline Secondary enrollment & $-0.089^{* * *}(0.024)$ & $-0.072(0.049)$ & $-0.189(0.191)$ & $-0.426(0.407)$ \\
\hline Tertiary enrollment & $0.052 * *(0.023)$ & $-0.070(0.047)$ & $0.122(0.134)$ & $-0.271 *(0.146)$ \\
\hline Health expenditure & $-0.233(0.197)$ & $0.278(0.259)$ & $0.224(0.276)$ & $-0.365^{* *}(0.170)$ \\
\hline PGI $\times$ Primary enrollment & & & $-0.072(0.040) *$ & \\
\hline PGI $\times$ Secondary enrollment & & & $-0.009(0.005) *$ & \\
\hline PGI $\times$ Tertiary enrollment & & & $-0.002(0.001)^{* *}$ & \\
\hline PGI $\times$ Health expenditure & & & & $-0.003(0.001) *$ \\
\hline Constant & $19.176^{* * *}(6.113)$ & $54.925^{* * *}(11.329)$ & $31.424(9.838)^{* * *}$ & $66.657^{* *}(25.56)$ \\
\hline Observations & 454 & 454 & 454 & 454 \\
\hline Number of countries & 34 & 34 & 34 & 34 \\
\hline \multicolumn{5}{|l|}{ (C) Social globalization } \\
\hline SGI & $-0.330 * * *(0.061)$ & $-0.186^{* *}(0.095)$ & $-0.175^{* *}(0.089)$ & $-0.130 * *(0.054)$ \\
\hline Primary enrollment & $-0.045(0.050)$ & $-0.168^{* * *}(0.062)$ & $-0.167(0.128)$ & $0.529(1.009)$ \\
\hline Secondary enrollment & $-0.030(0.025)$ & $-0.044(0.045)$ & $-0.137(0.185)$ & $-0.264(0.099)$ \\
\hline Tertiary enrollment & $0.103^{* * *}(0.025)$ & $-0.094 *(0.049)$ & $0.088(0.147)$ & $-0.191 *(0.101)$ \\
\hline Health expenditure & $-0.122(0.188)$ & $0.460 *(0.268)$ & $0.428(0.274)$ & $-0.162 *(0.089)$ \\
\hline SGI $\times$ Primary enrollment & & & $-0.021(0.018)$ & \\
\hline SGI $\times$ Secondary enrollment & & & $-0.010^{* * *}(0.002)$ & \\
\hline SGI $\times$ Tertiary enrollment & & & $-0.072 * *(0.003)$ & \\
\hline SGI $\times$ Health expenditure & & & & $-0.011(0.001) *$ \\
\hline Constant & $22.700(6.383) * * *$ & $42.790^{* *}(18.120)$ & $59.621(15.946)^{* * *}$ & $44.058 * *(18.703)$ \\
\hline Observations & 454 & 454 & 454 & 454 \\
\hline Number of Countries & 34 & 34 & 34 & 34 \\
\hline
\end{tabular}

Notes: (1) Robust standard errors in parentheses. ${ }^{* * *} p<0.01,{ }^{* *} p<0.05,{ }^{*} p<0.1$. (2) All the variables are in logarithmic forms. (3) Only Model (6), (7) and (8) include control variables but not reported.

\subsection{The Effect of Overall Globalization and Human Capital on Child Mortality Rate}

We present the results of three regressions estimated with child mortality rate as the dependent variable in Table 4. Model (9) is the base model. Model (10) adds all the control variables. Model (11) includes controls and the interaction between overall globalization index (OGI) and the education dimension of human capital (primary enrollment, secondary enrollment, tertiary enrollment). Finally, model (12) adds the interaction between OGI and the health dimension of human capital (health expenditure).

The results reveal, with regards to model (9) and model (10), that aggregate globalization is negatively associated with child mortality rate in developing countries. Specifically, as in model (9), an increase in the level of OGI by $10 \%$ could lead to a reduction in the rate of death of under-five children (per 1000 live birth) by $8.6 \%$ in poor countries. By illustration, had the OGI of Afghanistan (in 2015) increased from 38 to 41 units, and had all other things remained equal, it could have significantly reduced under-five child mortality from 73 to 66 per 1000 live birth. This feat could be attained if, for example, the government of Afghanistan reduces the import tariffs on antibiotics and vaccines, signs more international health treaties, and perhaps promotes medical tourism. The findings are consistent with the studies by Welander et al. (2015) and Ha and Cain (2017), which stressed that global integration [with particular reference to trade openness in the study by Ha and Cain (2017)] 
by developing countries is positively associated with fewer deaths of children from severe diseases such as respiratory infections, chicken pox, and meningitis. The coefficients of primary, secondary, and tertiary school enrollment retain negative signs across all the models, revealing that the stock of knowledge is negatively associated with child mortality rate. With reference to model (10), an increase in primary, secondary, and tertiary school enrollment by $10 \%$ could significantly reduce the likelihood that parents in developing countries would lose their children before age five by $1.1 \%$, $2.5 \%$, and $6.0 \%$, respectively. The empirical findings confirm the significance of education, especially maternal education, in reducing child poverty and mortality in developing countries, as reported in the studies by Grépin and Bharadwaj (2015) for Zimbabwe and by Ashagidigbi et al. (2018) for Nigeria. Similarly, the coefficient of the health dimension of human capital (health expenditure) is negative and significantly different from zero across all the models. This is in line with a prior expectation that improved health systems in developing countries could reduce child mortality significantly. Bloom et al. (2004) reported similar results. Similarly, in model (12), countries with high health human capital are associated with reduction in child mortality, suggesting that good health structures and systems are associated with better management of the globalization effect on child mortality rate of the poor. The health dimension of human capital seems to be more in the globalization-child mortality relationship relative to the education dimension of human capital.

Table 4. Estimation results, the effect of overall globalization and human capital on child mortality rate (per 1000 live birth).

\begin{tabular}{|c|c|c|c|c|}
\hline Dependent Variable: Child Mortality Rate & (9) & (10) & (11) & (12) \\
\hline OGI & $\begin{array}{c}-0.860^{* * *} \\
(0.069)\end{array}$ & $\begin{array}{l}-0.325 \\
(0.404)\end{array}$ & $\begin{array}{c}-0.512 * * * \\
(0.047)\end{array}$ & $\begin{array}{c}-0.606^{* *} \\
(0.277)\end{array}$ \\
\hline Primary enrollment & $\begin{array}{c}-0.551^{* * *} \\
(0.031)\end{array}$ & $\begin{array}{c}-0.107^{* *} \\
(0.043)\end{array}$ & $\begin{array}{c}-0.589^{* * * *} \\
(0.171)\end{array}$ & $\begin{array}{c}-0.122 * \\
(0.063)\end{array}$ \\
\hline Secondary enrollment & $\begin{array}{c}-0.105^{* * *} \\
(0.040)\end{array}$ & $\begin{array}{c}-0.247^{* *} \\
(0.120)\end{array}$ & $\begin{array}{c}-1.444^{* * *} \\
(0.224)\end{array}$ & $\begin{array}{c}-0.235^{\text {*** }} \\
(0.043)\end{array}$ \\
\hline Tertiary enrollment & $\begin{array}{c}-0.494^{* * *} \\
(0.045)\end{array}$ & $\begin{array}{c}-0.605^{* * *} \\
(0.070)\end{array}$ & $\begin{array}{c}-0.535^{* * * *} \\
(0.176)\end{array}$ & $\begin{array}{c}-0.093^{* * *} \\
(0.034)\end{array}$ \\
\hline Health expenditure & $\begin{array}{c}-0.840^{* * *} \\
(0.198)\end{array}$ & $\begin{array}{c}-0.686^{* * *} \\
(0.131)\end{array}$ & $\begin{array}{c}-0.733^{* * *} \\
(0.057)\end{array}$ & $\begin{array}{c}-0.942 * * \\
(0.382)\end{array}$ \\
\hline Rural population & & $\begin{array}{c}-0.417 \\
(0.500)\end{array}$ & $\begin{array}{l}-0.240 \\
(0.973)\end{array}$ & $\begin{array}{c}-0.864^{* * *} \\
(0.059)\end{array}$ \\
\hline Population growth & & $\begin{array}{c}0.508^{* *} \\
(0.026)\end{array}$ & $\begin{array}{c}0.099 \\
(1.452)\end{array}$ & $\begin{array}{c}0.327 \\
(1.540)\end{array}$ \\
\hline Arable land & & $\begin{array}{c}0.531^{* *} \\
(0.243)\end{array}$ & $\begin{array}{c}0.223^{* * *} \\
(0.010)\end{array}$ & $\begin{array}{c}0.506^{* *} \\
(0.285)\end{array}$ \\
\hline GDP growth & & $\begin{array}{l}-0.074 \\
(0.148)\end{array}$ & $\begin{array}{l}-0.053 \\
(0.069)\end{array}$ & $\begin{array}{c}0.031 \\
(0.060)\end{array}$ \\
\hline GDP per capital & & $\begin{array}{c}-0.100 * * \\
(0.050)\end{array}$ & $\begin{array}{c}-0.120 * * \\
(0.053)\end{array}$ & $\begin{array}{c}-0.117^{* *} \\
(0.051)\end{array}$ \\
\hline Inflation rate & & $\begin{array}{c}0.113 \\
(0.136)\end{array}$ & $\begin{array}{c}0.211 \\
(0.154)\end{array}$ & $\begin{array}{c}0.356 \\
(0.201)\end{array}$ \\
\hline Access to electricity & & $\begin{array}{l}-0.244 \\
(0.176)\end{array}$ & $\begin{array}{l}-0.020 \\
(0.058)\end{array}$ & $\begin{array}{l}-0.004 \\
(0.082)\end{array}$ \\
\hline OGI $\times$ Primary enrollment & & & $\begin{array}{c}0.010^{* * *} \\
(0.004)\end{array}$ & \\
\hline OGI $\times$ Secondary enrollment & & & $\begin{array}{c}0.024^{* * *} \\
(0.004)\end{array}$ & \\
\hline OGI $\times$ Tertiary enrollment & & & $\begin{array}{c}-0.007^{* *} \\
(0.003)\end{array}$ & \\
\hline OGI $\times$ Health expenditure & & & & $\begin{array}{c}0.091^{* * *} \\
(0.019)\end{array}$ \\
\hline Constant & $\begin{array}{c}14.255^{* * *} \\
(2.417)\end{array}$ & $\begin{array}{c}28.987^{* * *} \\
(5.143)\end{array}$ & $\begin{array}{c}15.121^{* * *} \\
(2.620)\end{array}$ & $\begin{array}{c}18.809^{* * * *} \\
(11.914)\end{array}$ \\
\hline Observations & 1792 & 1792 & 1792 & 1792 \\
\hline Number of countries & 110 & 110 & 110 & 110 \\
\hline $\operatorname{AR}(1) p$-value & 0.000 & 0.003 & 0.001 & 0.000 \\
\hline $\mathrm{AR}(2) p$-value & 0.829 & 0.650 & 0.711 & 0.830 \\
\hline Hansen test $p$-value & 0.714 & 0.516 & 0.247 & 0.617 \\
\hline
\end{tabular}

Notes: (1) Robust standard errors in parentheses. ${ }^{* * *} p<0.01,{ }^{* *} p<0.05,{ }^{*} p<0.1$. (2) All the variables are in logarithmic forms. 
Turning to the interaction terms, we find that OGI significantly affects the child mortality rate, and the effect becomes strongest when the interaction between globalization and secondary enrollment is considered. The interaction term between OGI and secondary enrollment seems to contribute most to the globalization effect on child mortality rate relative to other measures of education human capital. This indicates that developing countries that benefit most from globalization in its effect on child mortality reduction are those that have high enrollment in secondary schools.

With regards to the control variables, as expected, the results reveal that GDP per capita is negatively associated with child mortality. The population growth is associated with an increase in child mortality. This may lend support to the findings of Grépin and Bharadwaj (2015) that reveal that households with large household size are constraints with available resources, thereby lacking the wherewithal to sufficiently take good care of their children. Contrary to expectations, we find that arable land is positively associated with high child mortality. A possible explanation for this is that women in developing countries tend to engage in heavy agricultural activities during pregnancy, resulting in defects in the health status of children and thereby increasing the potential of high mortality before children reach the age of five. Similar findings were reported by Grépin and Bharadwaj (2015), who found that intense agricultural production significantly affects maternal health during pregnancy, thereby resulting in about $4 \%$ infant mortality in Zimbabwe. Consistently, inflation rate has a positive relationship with child mortality rate, suggesting that unstable macroeconomic policies could reduce the chance of survival of children in developing countries. Unsurprisingly, access to infrastructure is negatively associated with child mortality rate. This result lends support to the study of Olagunju et al. (2018) that found welfare impacts rural infrastructural development in reducing the likelihood of a child being poor.

\subsection{Exploring Disaggregated Globalization Index, Human Capital, and Child Mortality Rate}

Table 5 reports the relationships between the three dimensions of globalization, human capital, and child mortality rate (per 1000 live birth). Model (14) reveals that a 10\% increase in the EGI could reduce child mortality rate by $1.8 \%$. This indicates that the level of economic integration into the world economy is associated with a reduction in the child mortality rate in developing countries. One likely explanation for this is that economic integration tends to increase flow of capital, resulting in an increase in national incomes and enabling households to invest more in the health of their children. The findings are in line with results of Ha and Cain (2017), who found that trade openness could reduce child mortality rate in developing countries. The coefficients of the interaction terms are all negative, which indicates a complementary effect whereby education and health human capital strengthen the effect of economic globalization on child mortality. In other words, the impact of economic globalization on child mortality rates can be stronger if education human capital development improves in the developing economies. The interaction term of EGI and primary education is the only significant human capital measure. Similarly, as in models (13), (14), (15), and (16), we find that increases in SGI and PGI are associated with reduction in child mortality, indicating that, should a country increase its level of social and political globalization, it could result in a significant reduction in child mortality rate. As in models (15) and (16), the coefficients of the interaction terms are all negative, indicating a complementary effect whereby education and health human capital strengthens the impact of social and political globalization in child mortality rate reduction. Overall, the health dimension of human capital tends to be most important in the complementary roles of the stock of human capital in the globalization-child mortality relationship in developing countries. 
Table 5. Estimation results, the effect disaggregated globalization index and human capital on child mortality rate (per 1000 live birth).

\begin{tabular}{|c|c|c|c|c|}
\hline Dependent Variable: Child Mortality Rate & (13) & (14) & (15) & (16) \\
\hline \multicolumn{5}{|l|}{ (A) Economic globalization } \\
\hline EGI & $-0.225(0.221)$ & $-0.189^{* * *}(0.067)$ & $-1.021(0.687)$ & $-0.171^{* * *}(0.027)$ \\
\hline Primary enrollment & $-0.596^{* * *}(0.032)$ & $-0.248 *(0.131)$ & $-0.683^{* *}(0.280)$ & $0.001(0.021)$ \\
\hline Tertiary enrollment & $0.326^{* * *}(0.039)$ & $-0.015(0.184)$ & $-0.199(0.537)$ & $-0.003(0.002)$ \\
\hline Health expenditure & $-0.319^{* * *}(0.001)$ & $-0.452 * * *(0.013)$ & $-0.896^{* * *}(0.189)$ & $-0.230^{* * *}(0.026)$ \\
\hline EGI × Primary enrollment & & & $-0.011^{* *}(0.005)$ & \\
\hline EGI $\times$ Secondary enrollment & & & $-0.001(0.001)$ & \\
\hline EGI × Tertiary enrollment & & & $-0.004(0.001)$ & \\
\hline EGI $\times$ Health expenditure & & & & $-0.042^{* * *}(0.006)$ \\
\hline Constant & $13.642 * * *(1.047)$ & $9.6314 * * *(2.589)$ & $10.437^{* * *}(2.780)$ & $5.481^{* * *}(2.078)$ \\
\hline Observations & 1792 & 1792 & 1792 & 1792 \\
\hline Number of countries & 110 & 110 & 110 & 110 \\
\hline \multicolumn{5}{|l|}{ (B) Political globalization } \\
\hline PGI & $-0.683^{* * *}(0.045)$ & $-0.201(0.012)^{* * *}$ & $-0.198(0.214)$ & $-0.156^{* * *}(0.031)$ \\
\hline Primary enrollment & $-0.519^{* * *}(0.030)$ & $-0.247^{* *}(0.116)$ & $-0.342(0.253)$ & $0.243(0.601)$ \\
\hline Secondary enrollment & $-0.113^{* * *}(0.038)$ & $-0.094(0.144)$ & $-0.196(0.423)$ & $-0.019(0.013)$ \\
\hline Tertiary enrollment & $0.444^{* * *}(0.037)$ & $0.103(0.170)$ & $0.052(0.500)$ & $-0.029(0.018)$ \\
\hline Health expenditure & $-0.795^{* * *}(0.193)$ & $-0.588^{* * *}(0.128)$ & $-0.621^{* * *}(0.185)$ & $-0.668(0.415)$ \\
\hline PGI $\times$ Primary enrollment & & & $-0.002(0.005)$ & \\
\hline PGI $\times$ Secondary enrollment & & & $-0.002(0.007)$ & \\
\hline PGI $\times$ Tertiary enrollment & & & $-0.001(0.006)$ & \\
\hline PGI $\times$ Health expenditure & & & & $-0.038^{* * *}(0.007)$ \\
\hline Constant & $13.946^{* * *}(1.048)$ & $10.003^{* * *}(2.571)$ & $11.924^{* * *}(2.162)$ & $5.900^{* * *}(2.053)$ \\
\hline Observations & 1792 & 1792 & 1792 & 1792 \\
\hline Number of countries & 110 & 110 & 110 & 110 \\
\hline \multicolumn{5}{|l|}{ (C) Social globalization } \\
\hline SGI & $-0.589^{* * *}(0.066)$ & $-0.269(0.251)$ & $-0.317(0.249)$ & $0.208^{* * *}(0.032)$ \\
\hline Primary enrollment & $-0.559^{* * *}(0.031)$ & $-0.230 *(0.139)$ & $-0.255^{*}(0.134)$ & $-0.002(0.008)$ \\
\hline Secondary enrollment & $-0.108^{* * *}(0.041)$ & $-0.085(0.138)$ & $-0.003(0.387)$ & $-0.002(0.001)$ \\
\hline Tertiary enrollment & $0.427^{* * *}(0.039)$ & $0.025(0.167)$ & $-0.381(0.515)$ & $-0.002(0.002)$ \\
\hline Health expenditure & $-0.141^{* * *}(0.097)$ & $-0.999 * * *(0.059)$ & $-0.886^{* * *}(0.208)$ & $-0.018^{* * *}(0.083)$ \\
\hline SGI $\times$ Primary enrollment & & & $-0.003(0.004)$ & \\
\hline SGI $\times$ Secondary enrollment & & & $-0.002(0.006)$ & \\
\hline SGI $\times$ Tertiary enrollment & & & $-0.005(0.006)$ & \\
\hline SGI $\times$ Health expenditure & & & & $-0.052^{* * *}(0.008)$ \\
\hline Constant & $14.4336^{* * *}(1.0526)$ & $10.4675^{* * *}(2.719)$ & $12.407^{* * *}(3.090)$ & $8.378^{* * *}(2.113)$ \\
\hline Observations & 1792 & 1792 & 1792 & 1792 \\
\hline Number of Countries & 110 & 110 & 110 & 110 \\
\hline
\end{tabular}

Notes: (1) Robust standard errors in parentheses. ${ }^{* * *} p<0.01,{ }^{* *} p<0.05,{ }^{*} p<0.1$. (2) All the variables are in logarithmic forms. (4) All the models include control variables except model (13).

By comparing the coefficients of EGI, SGI, and PGI, which are $0.189,0.181$, and 0.269 , respectively, the results show that political and social globalization have more significant effects on the reduction child mortality rate than economic globalization. This suggests that the negative coefficient of OGI comes from both the political and the social dimensions rather than from the economic dimension.

\subsection{Robustness Checks}

We conduct several robustness tests of our main findings, as reported in Table 6. According to Sachs and Warner (1997), economic growth and the level of interconnectedness of a country can be influenced by the country's geographical features; for example, whether a country is landlocked or not may determine the extent of access to international markets. Similarly, developing countries that are subjected to tropical climates are exposed to agri-climatic constraints, which may contribute negatively to the agricultural productivity and supply, thereby reducing their participation in trade. This can negatively influence overall economic growth and development. First, with this understanding, we test 
the sensitivity of our results to regional specification by including a tropics dummy ${ }^{3}$. As presented in models (17)-(20), we find that the coefficients of OGI variable remain negative and significant. Also, we find coefficients of the interaction terms to be negative, as expected. These results are consistent with our core findings. Second, we attempt to examine the sensitivity of our findings with regards to alternative measure of welfare. In doing this, we focus our attention to the use of alternative welfare indicators, which are available for the same period and set of countries as employed in our core analysis. We employ poverty headcount and infant mortality rate as alternative measures for poverty gap and child mortality rate, respectively. Results, as reported in models (21)-(24), confirm the observations for our core models with poverty gap and child mortality rate as dependent variables. Given that the equation with poverty gap (34 countries) as the dependent variable is a subsample of the countries used for the child mortality equation (110 countries), we further perform a robustness analysis using the 34-country subsample for child mortality. The results, as presented in models (25) and (26), also confirm our main findings.

Table 6. Robustness tests for our analysis.

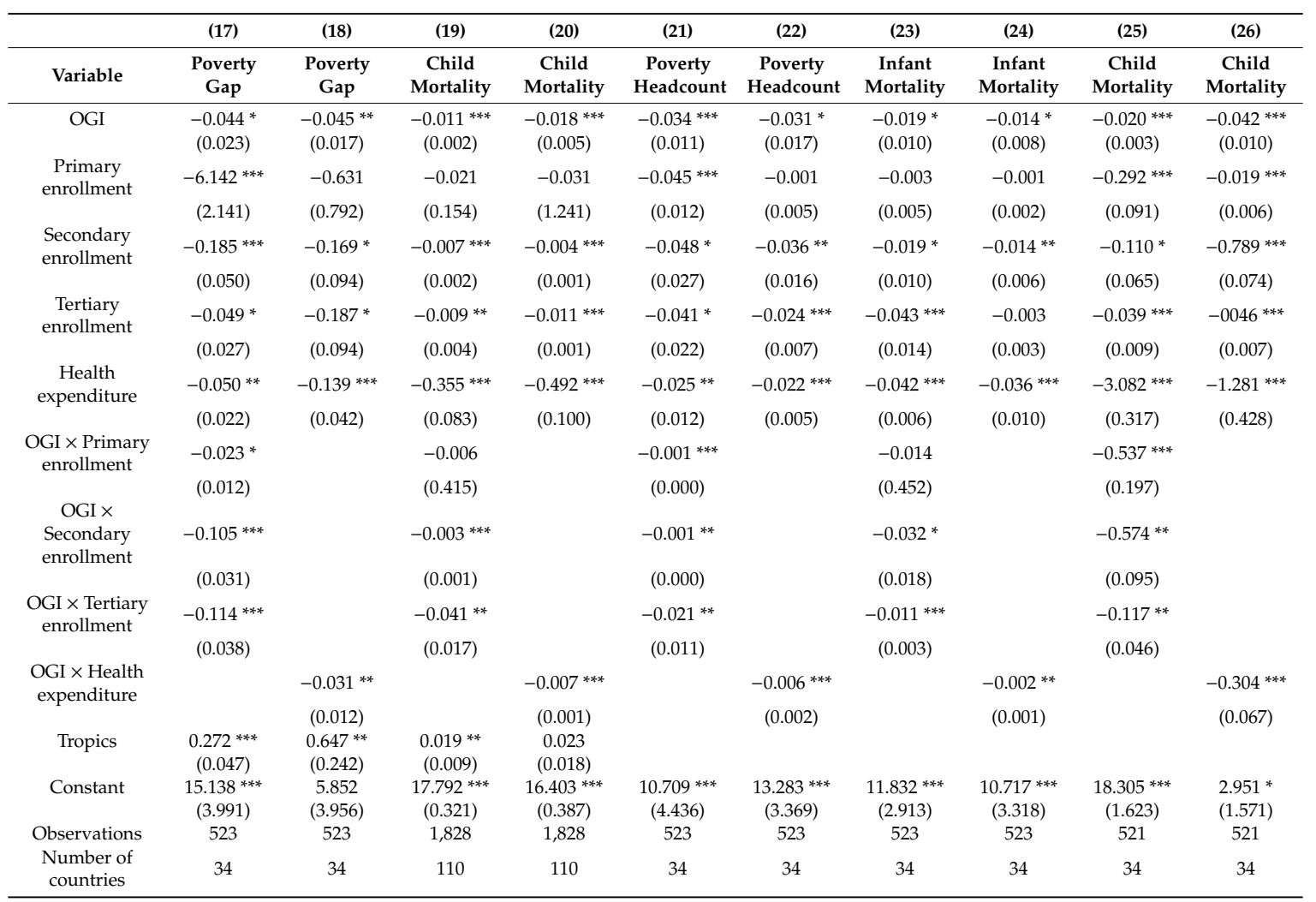

Notes: (1) Robust standard errors in parentheses. ${ }^{* * *} p<0.01,{ }^{* *} p<0.05,{ }^{*} p<0.1$. (2) All the main independent variables are lagged one year. (3) All the variables are in logarithmic forms. (4) All the models include control variables, but these are not presented.

\section{Concluding Remarks}

In the present study, we employ cross-country panel data to analyze the moderating role of human capital in the impact of globalization on welfare in developing countries. We use an SGMM estimation technique to account for unobserved heterogeneity. This approach is able to correct for potential endogeneity that may arise in the estimation. The article contributes to the ongoing debate on the impact of globalization on welfare of the poor by exploring the mediating role of human capital.

3 We follow Dithmer and Abdulai (2017) classification typology based on the share of population living in geographical tropics. See Dithmer and Abdulai (2017) for details. 
Our empirical results reveal that aggregate globalization index is, on average, associated with lower poverty gap and child mortality rate, which leads us to conclude that the benefits of globalization outweigh its cost in terms of reduction of the poverty gap and the child mortality rate in developing countries. An interesting revelation from this study is that the education and the health dimensions of human capital strengthen the impact of aggregate globalization on poverty gap and child mortality rate. Specifically, the study reveals that developing countries that benefit more from globalization are those that have high enrollment in secondary and tertiary education and high stock of health capital. Further insights from our study reveal that political and social integration are the driving forces behind the negative relationship between globalization, poverty gap, and child mortality rate. We also find strong evidence that agricultural, economic, and infrastructural development as well as beneficial macroeconomic policy impact welfare positively.

From a policy perspective, some recommendations can be offered from our findings. Most importantly, our results point to the importance of a country's level of globalization and human capital development for welfare of the poor. Globalization supporting activities and promotion of human capital development should therefore constitute a fundamental component of a policy mix to enhance reduction in poverty gap and child mortality rate. For example, the signing of more international treaties, the promotion of flow information and technical know-how, and the elimination of trade distorting policies being complemented by an improvement in government expenditure on education and health could all be effective instruments for this purpose. This is to ensure that citizens in developing countries are better able to explore and take full advantage of economic, social, and political integration.

In addition, our results reveal that general economic and infrastructural development are keys for improving welfare in developing countries, suggesting that policy instruments such as policies targeted at building infrastructure and improving productivity of economic sectors should be included as components of national welfare improvement strategies; for instance, increasing government spending on public goods, stabilizing economic and environmental climates for low inflation, promoting structural transformation, etc.

Finally, we acknowledge the limitations associated with the study, which provides several avenues for further research. First, considering that the interactive effect of different measures of human capital varies, we suggest that future studies should examine some other dimensions of human capital apart from education and health dimensions that we consider in the present study. Other dimensions of human capital worth studying include social capital, emotional capital, creativity, cultural capital, and relational capital. Despite the limitation of our study (largely due to lack of reliable cross-national data), as new data become available, future studies can follow our general approach to retest these relationships.

Author Contributions: Conceptualization, K.O.O. and A.I.O.; methodology, K.O.O., A.I.O., K.F.O. and K.O.; software, K.O.O.; formal analysis, K.O.O. and A.I.O.; data curation, K.F.O. and I.O.R.; writing-original draft preparation, K.O.O., A.I.O., K.F.O., I.O.R. and K.O.; writing—review and editing, K.O.O., A.I.O., K.F.O., I.O.R. and K.O.; supervision, K.O.O. and K.O.

Funding: This research received no external funding.

Conflicts of Interest: The authors declare no conflict of interest. 


\section{Appendix A}

Table A1. List of countries.

\begin{tabular}{|c|c|c|c|}
\hline Afghanistan & Dominica & Lebanon & Rwanda \\
\hline Albania & Dominican Republic & Lesotho & Samoa \\
\hline Algeria & Ecuador & Liberia & Sao Tome and Principe \\
\hline American Samoa & Egypt & Libya & Senegal \\
\hline Angola & El Salvador & Macedonia FYR & Serbia \\
\hline Armenia & Equatorial Guinea & Madagascar & Sierra Leone \\
\hline Bangladesh & Eritrea & Malawi & Solomon Islands \\
\hline Belarus & Ethiopia & Malaysia & Somalia \\
\hline Belize & Fiji & Maldives & South Africa \\
\hline Benin & Gabon & Mali & Sri Lanka \\
\hline Bhutan & Gambia & Marshall Islands & St Lucia \\
\hline Bolivia & Georgia & Mauritania & St Vincent and the Grenadines \\
\hline $\begin{array}{l}\text { Bosnia and } \\
\text { Herzegovina }\end{array}$ & Ghana & Mauritius & Sudan \\
\hline Botswana & Grenada & Mexico & Suriname \\
\hline Brazil & Guatemala & Micronesia Fed Sts & Syrian Arab Republic \\
\hline Bulgaria & Guinea & Moldova & Tajikistan \\
\hline Burkina Faso & Guinea Bissau & Mongolia & Tanzania \\
\hline Burundi & Guyana & Montenegro & Thailand \\
\hline Cabo Verde & Haiti & Morocco & Timor-Leste \\
\hline Cambodia & Honduras & Mozambique & Togo \\
\hline Cameroon & India & Myanmar & Tonga \\
\hline $\begin{array}{c}\text { Central African } \\
\text { Republic }\end{array}$ & Indonesia & Namibia & Tunisia \\
\hline Chad & Iran Islamic Rep & Nepal & Turkey \\
\hline China & Iraq & Nicaragua & Turkmenistan \\
\hline Colombia & Jamaica & Niger & Uganda \\
\hline Comoros & Jordan & Nigeria & Ukraine \\
\hline Congo Dem. Rep & Kazakhstan & Pakistan & Uzbekistan \\
\hline Congo Rep & Kenya & Papua New Guinea & Vanuatu \\
\hline Costa Rica & Kiribati & Paraguay & Venezuela RB \\
\hline Cote d'Ivoire & Korea & Peru & Vietnam \\
\hline Cuba & Kyrgyz Republic & Philippines & West Bank and Gaza \\
\hline \multirow[t]{3}{*}{ Djibouti } & Lao PDR & Romania & Yemen Rep \\
\hline & & Russian Federation & Zambia \\
\hline & & & Zimbabwe \\
\hline
\end{tabular}

Table A2. Components of KOF Globalization Index.

\begin{tabular}{cl}
\hline Components & \multicolumn{1}{c}{ Measure } \\
\hline \multirow{2}{*}{ Economic } & $\begin{array}{l}\text { (i) Actual flows: Trade (in percentage of GDP), foreign direct investment (in percentage of GDP), portfolio investment (in } \\
\text { percentage of GDP), and income payments to foreign nationals (in percentage of GDP). } \\
\text { (ii) Policies: Mean tariff rate, hidden import barriers, taxes on international trade (in percentage of current revenue), and } \\
\text { capital account restrictions. }\end{array}$ \\
\hline Social & $\begin{array}{l}\text { (i) Personal contact: Outgoing telephone traffic, transfers (in percentage of GDP), international tourism, telephone average } \\
\text { costs of call to USA, foreign population (in percentage of total population). } \\
\text { (ii) Data on information flows: Telephone mainlines (per 1000 people), internet hosts (per capita), internet users (as a share of } \\
\text { population), cable television (per 1000 people), daily newspapers (per 1000 people), and radios (per 1000 people). } \\
\text { (iii) Data on cultural proximity: McDonald's and IKEA per capita, trade in books (\% of GDP). }\end{array}$ \\
\hline Political & Embassies in country, membership in international organizations, participation in UN Security Council missions. \\
\hline
\end{tabular}

Table A3. Correlations of the explanatory variables.

\begin{tabular}{|c|c|c|c|c|c|c|c|c|c|c|c|c|c|c|c|c|}
\hline Variable & & (1) & (2) & (3) & (4) & (5) & (6) & (7) & (8) & (9) & (10) & (11) & (12) & (13) & (14) & (15) \\
\hline OGI & (1) & 1.00 & & & & & & & & & & & & & & \\
\hline EGI & (2) & 0.68 & 1.00 & & & & & & & & & & & & & \\
\hline SGI & (3) & 0.76 & 0.46 & 1.00 & & & & & & & & & & & & \\
\hline Primary enrollment & (5) & 0.40 & 0.32 & 0.39 & 0.16 & 1.00 & & & & & & & & & & \\
\hline Secondary enrollment & (6) & 0.41 & 0.46 & 0.36 & 0.31 & 0.26 & 1.00 & & & & & & & & & \\
\hline Tertiary enrollment & (7) & 0.37 & 0.42 & 0.45 & 0.45 & 0.30 & 0.17 & 1.00 & & & & & & & & \\
\hline Rural population & (8) & 0.08 & -0.22 & -0.14 & 0.25 & 0.05 & 0.00 & -0.05 & 1.00 & & & & & & & \\
\hline Arable land area & (11) & 0.08 & -0.24 & -0.08 & 0.35 & 0.04 & 0.06 & 0.13 & 0.44 & -0.41 & -0.08 & 1.00 & & & & \\
\hline GDP growth & (12) & 0.02 & 0.06 & -0.03 & 0.03 & 0.02 & -0.10 & -0.07 & 0.07 & -0.24 & 0.14 & 0.04 & 1.00 & & & \\
\hline GDP per capita & (13) & 0.26 & 0.33 & 0.16 & 0.28 & 0.28 & 0.31 & 0.29 & -0.05 & 0.06 & -0.27 & 0.13 & 0.02 & 1.00 & & \\
\hline Inflation & (14) & -0.03 & -0.04 & -0.04 & 0.01 & -0.01 & 0.00 & 0.03 & -0.01 & 0.02 & 0.12 & 0.19 & -0.08 & -0.03 & 1.00 & \\
\hline Access to electricity & (15) & 0.39 & 0.36 & 0.28 & 0.25 & 0.40 & 0.44 & 0.37 & 0.06 & 0.26 & -0.11 & 0.14 & -0.02 & 0.14 & -0.03 & 1.00 \\
\hline
\end{tabular}




\section{References}

Acemoglu, Daron, and Simon Johnson. 2007. Disease and development: the effect of life expectancy on economic growth. Journal of Political Economy 115: 925-85. [CrossRef]

Agénor, Pierre-Richard. 2002. Does Globalization Hurt the Poor? Washington: The World Bank.

Alaverdyan, Davit, Henrietta Nagy, Ira Panosyan, and Olagunju Kehinde. 2015. The impact of technology evaluation programme on agrIcultural productivity in Armenia. Visegrad Journal on Bioeconomy and Sustainable Development 4: 62-69. [CrossRef]

Ames, Brian, Ward Brown, Shanta Devarajan, and Alejandro Izquierdo. 2001. Macroeconomic Policy and Poverty Reduction. Washington: International Monetary Fund.

Arellano, Manuel, and Stephen Bond. 1991. Some tests of specification for panel data: Monte Carlo evidence and an application to employment equations. The Review of Economic Studies 58: 277-97. [CrossRef]

Arribas, Iván, Francisco Pérez, and Emili Tortosa-Ausina. 2009. Measuring globalization of international trade: Theory and evidence. World Development 37: 127-45. [CrossRef]

Ashagidigbi, Waheed M., Adewumi Oluwatosin B., Kehinde Olagunju, and Adebayo Ogunniyi. 2018. Maternal Education Household's Wealth and Child Mortality in Rural Nigeria. Journal of Nutritional Biology 4: 207-16.

Azizi, SeyedSoroosh. 2018. The impacts of workers' remittances on human capital and labor supply in developing countries. Economic Modelling 75: 377-96. [CrossRef]

Barro, Robert J. 2013. Education and Economic Growth. Annals of Economics and Finance 14: 3001-328.

Barro, Robert J., and Jong-Wha Lee. 1994. Sources of economic growth. Carnegie-Rochester Conference Series on Public Policy 40: 1-46. [CrossRef]

Bechtel, Gordon G. 2014. Does globalization mitigate income inequality. Journal of Data Science 12: $197-215$.

Bergh, Andreas, and Therese Nilsson. 2014. Is globalization reducing absolute poverty? World Development 62: 42-61. [CrossRef]

Bhagwati, Jagdish, and Thirukodikaval Nilakanta Srinivasan. 2002. Trade and poverty in the poor countries. American Economic Review 92: 180-83. [CrossRef]

Bloom, David E., David Canning, and Jaypee Sevilla. 2004. The effect of health on economic growth: A production function approach. World Development 32: 1-13. [CrossRef]

Bloom, David E., David Canning, Günther Fink, and Jocelyn E. Finlay. 2013. Program on the global demography of aging. Europe 30: 35.

Blundell, Richard, and Stephen Bond. 1998. Initial conditions and moment restrictions in dynamic panel data models. Journal of Econometrics 87: 115-43. [CrossRef]

Borensztein, Eduardo, Jose De Gregorio, and Jong-Wha Lee. 1998. How does foreign direct investment affect economic growth? Journal of International Economics 45: 115-35. [CrossRef]

Bourguignon, Francois. 2002. Making Sense of Globalization: A Guide to the Economic Issues. London: Centre for Economic Policy Research.

Brian, Keeley. 2007. OECD Insights Human Capital How What You Know Shapes Your Life: How What You Know Shapes Your Life.. Paris: OECD publishing.

Calderón, César, and Alberto Chong. 2001. External sector and income inequality in interdependent economies using a dynamic panel data approach. Economics Letters 71: 225-31. [CrossRef]

Chang, Roberto, Linda Kaltani, and Norman V. Loayza. 2009. Openness can be good for growth: The role of policy complementarities. Journal of Development Economics 90: 33-49. [CrossRef]

Cowell, Frank A., Francisco H. G. Ferreira, and Julie A. Litchfield. 1998. Income distribution in brazil 1981-1990 parametric and non-parametric approaches. Journal of Income Distribution 8: 63-76. [CrossRef]

Deaton, Angus. 2004. Health in an Age of Globalization. Washington: The Brookings Institution.

Dimitriadis, Nikolaos I., and S. C. Lenny Koh. 2005. Information flow and supply chain management in local production networks: The role of people and information systems. Production Planning \& Control 16: 545-54.

Dithmer, Jan, and Awudu Abdulai. 2017. Does trade openness contribute to food security? A dynamic panel analysis. Food Policy 69: 218-30. [CrossRef]

Dollar, David. 2001. Is globalization good for your health? Bulletin of the world Health Organization 79: 827-33. [PubMed]

Dollar, David, and Aart Kraay. 2004. Trade, growth, and poverty. The Economic Journal 114: F22-49. [CrossRef] 
Dollar, David, Tatjana Kleineberg, and Aart Kraay. 2013. Growth Still is Good for the Poor. Washington: The World Bank.

Dreher, Axel, Noel Gaston, and Pim Martens. 2008. Measuring Globalisation: Gauging Its Consequences. New York: Springer Science \& Business Media.

Duncombe, Richard, and Richard Heeks. 1999. Information, ICTs and Small Enterprise: Findings from Botswana. Manchester: Institute for Development Policy and Management, University of Manchester.

Elbers, Chris, and Peter Lanjouw. 2001. Intersectoral transfer, growth, and inequality in rural Ecuador. World Development 29: 481-96. [CrossRef]

FAO. 2013. The State of Food Insecurity in the World 2014. Rome: FAO.

Feleke, Shiferaw T., Richard L. Kilmer, and Christina H. Gladwin. 2005. Determinants of food security in Southern Ethiopia at the household level. Agricultural Economics 33: 351-63. [CrossRef]

Gaston, Noel, and Gulasekaran Rajaguru. 2009. Has globalization increased Australian inequality. In Laggards and Leaders in Labor Market Reform: Comparing Japan And Australia. Abingdon: Routledge, pp. 85-108.

Gerring, John, Strom C. Thacker, and Rodrigo Alfaro. 2012. Democracy and human development. The Journal of Politics 74: 1-17. [CrossRef]

Ghobarah, Hazem Adam, Paul Huth, and Bruce Russett. 2004. Comparative public health: The political economy of human misery and Well-Being. International Studies Quarterly 48: 73-94. [CrossRef]

Glewwe, Paul, Eugenie Maiga, and Haochi Zheng. 2014. The contribution of education to economic growth: A review of the evidence, with special attention and an application to Sub-Saharan Africa. World Development 59: 379-93. [CrossRef]

Godfrey, Richard, and Marlene Julien. 2005. Urbanisation and health. Clinical Medicine 5: 137-41. [CrossRef] [PubMed]

Grépin, Karen A., and Prashant Bharadwaj. 2015. Maternal education and child mortality in Zimbabwe. Journal of health economics 44: 97-117. [CrossRef]

$\mathrm{Gu}$, Xinhua, and Baomin Dong. 2011. A Theory of Financial Liberalisation: Why are Developing Countries so Reluctant? The World Economy 34: 1106-23. [CrossRef]

Ha, Eunyoung, and Nicholas L. Cain. 2017. Who governs or how they govern: Testing the impact of democracy, ideology and globalization on the well being of the poor. The Social Science Journal 54: 271-86. [CrossRef]

Hanushek, Eric A., and Ludger Woessmann. 2008. The role of cognitive skills in economic development. Journal of Economic Literature 46: 607-68. [CrossRef]

Hartwig, Jochen. 2010. Is health capital formation good for long-term economic growth?-Panel Granger-Causality evidence for OECD countries. Journal of Macroeconomics 32: 314-25. [CrossRef]

Huay, Chong Siew, and Yasmin Bani. 2018. Remittances, poverty and human capital: Evidence from developing countries. International Journal of Social Economics 45: 1227-35. [CrossRef]

Kanbur, Ravi. 2000. Income distribution and development. Handbook of Income Distribution 1: 791-841.

Kremer, Michael, and Eric Maskin. 2003. Globalization and inequality. Harvard University, Department of Economics: Unpublished manuscript.

Le Goff, Maëlan, and Raju Jan Singh. 2014. Does trade reduce poverty? A view from Africa. Journal of African Trade 1: 5-14. [CrossRef]

Loayza, Norman V., Eduardo Olaberria, Jamele Rigolini, and Luc Christiaensen. 2012. Natural disasters and growth: Going beyond the averages. World Development 40: 1317-36. [CrossRef]

Lundberg, Mattias, and Lyn Squire. 2003. The simultaneous evolution of growth and inequality. The Economic Journal 113: 326-44. [CrossRef]

Maurer, Claus. 2013. The Measurement of Information Flow Efficiency in Supply Chain Management. Pretoria: University of South Africa.

Mayer, David. 2001. The long-term impact of health on economic growth in Latin America. World Development 29: 1025-33. [CrossRef]

McGuire, James W. 2006. Basic health care provision and under-5 mortality: A cross-national study of developing countries. World Development 34: 405-25. [CrossRef]

Mendez, Michelle, and Barry M. Popkin. 2004. Globalization, urbanization and nutritional change in the developing world. In Globalization of Food Systems in Developing Countries: Impact on Food Security and Nutrition. Rome: FAO. 
Murray, Christopher J. L., and Alan D. Lopez. 1997. Alternative projections of mortality and disability by cause 1990-2020: Global Burden of Disease Study. The Lancet 349: 1498-504. [CrossRef]

Neal, Derek A., and William R. Johnson. 1996. The role of premarket factors in black-white wage differences. Journal of Political Economy 104: 869-95. [CrossRef]

Newfarmer, Richard, and Monika Sztajerowska. 2012. Trade and employment in a fast-changing world. In Policy Priorities for International Trade and Jobs. Paris: OECD.

O'Neill, June. 1990. The role of human capital in earnings differences between black and white men. Journal of Economic Perspectives 4: 25-45. [CrossRef]

Ogundari, Kolawole, and Awudu Abdulai. 2014. Determinants of household's education and healthcare spending in Nigeria: Evidence from survey data. African Development Review 26: 1-14. [CrossRef]

Ogundari, Kolawole, and Titus Awokuse. 2018. Human capital contribution to economic growth in Sub-Saharan Africa: Does health status matter more than education? Economic Analysis and Policy 58: 131-40. [CrossRef]

Ogundari, Kolawole, and Shoichi Ito. 2015. Convergence and determinants of change in nutrient supply: Evidence from sub-Saharan African countries. British Food Journal 117: 2880-98. [CrossRef]

Ogunniyi, Adebayo, Kehinde Olagunju, Salman K. Kabir, and Ogundipe Adeyemi. 2016. Social crisis, terrorism and food poverty dynamics: Evidence from Northern Nigeria. International Journal of Economics and Financial Issues 6: 1865-72.

Ogunniyi, Adebayo, Kehinde Oluseyi Olagunju, Ogundipe Adeyemi, Salman K. Kabir, and Francis Philips. 2017. Scaling Up Agricultural Innovation for Inclusive Livelihood and Productivity Outcomes in Sub-Saharan Africa: The Case of Nigeria. African Development Review 29: 121-34. [CrossRef]

Ogunniyi, Adebayo, George Mavrotas, Kehinde Olagunju, Olusegun Fadare, and A. M. Rufai. 2018a. The Paradigm of Governance Quality, Migration and its Implication on Food and Nutritional Security in Sub-Saharan Africa: What does Dynamic Generalized Method of Moments estimation reveal? Paper presented at the International Association of Agricultural Economists (IAAE) 2018 Conference, Vancouver, BC, Canada, July 28-August 2.

Ogunniyi, Adebayo, Bolarin Omonona, Oyewale Abioye, and Kehinde Olagunju. 2018b. Impact of irrigation technology use on crop yield, crop income and household food security in Nigeria: A treatment effect approach. AIMS Agriculture and Food 3: 154-71.

Olagunju, Kehinde, and Adebayo Ogunniyi. 2015. The Assessment of the Impact of Rural Infrastructure on Rural Poverty in Nigeria. Economica (1585-6216) 8: 252-57.

Olagunju, Kehinde, Adebayo Oguninyi, and Kunle Oguntegbe. 2015. The Impact of Foreign Trade on Growth of Agricultural Output in Nigeria. International Journal of Innovation and Scientific Research 15: 207-16.

Olagunju, Kehinde Oluseyi, Adebayo Ogunniyi, and Mayokun Samuel Olufadewa. 2018. Spatial Analysis of Structural Determinants of Child Poverty Incidence in Nigeria. Paper presented at the International Association of Agricultural Economists (IAAE) 2018 Conference, Vancouver, BC, Canada, July 28-August 2.

Ophori, Endurance A., Musa Y. Tula, Azuka V. Azih, Rachel Okojie, and Precious E. Ikpo. 2014. Current trends of immunization in Nigeria: Prospect and challenges. Tropical Medicine and Health 42: 67-75. [CrossRef]

Papageorgiou, Chris, Andreas Savvides, and Marios Zachariadis. 2007. International medical technology diffusion. Journal of International Economics 72: 409-27. [CrossRef]

Perkins, Richard, and Eric Neumayer. 2005. The international diffusion of new technologies: A multitechnology analysis of latecomer advantage and global economic integration. Annals of the association of American Geographers 95: 789-808. [CrossRef]

Petrakis, Panagiotis E., and Dimitrios Stamatakis. 2002. Growth and educational levels: A comparative analysis. Economics of Education Review 21: 513-21. [CrossRef]

Ravallion, Martin. 2001. Growth, inequality and poverty: looking beyond averages. World Development 29: 1803-15. [CrossRef]

Ravallion, Martin. 2003. The debate on globalization, poverty and inequality: Why measurement matters. International Affairs 79: 739-53. [CrossRef]

Rena, Ravinder. 2005. Challenges for food security in Eritrea: A descriptive and qualitative analysis. African Development Review 17: 193-212. [CrossRef]

Rosenzweig, Mark R. 1988. Human capital, population growth, and economic development: Beyond correlations. Journal of Policy Modeling 10: 83-111. [CrossRef] 
Sachs, Jeffrey D., and Andrew M. Warner. 1997. Sources of slow growth in African economies. Journal of African Economies 6: 335-76. [CrossRef]

Sapkota, Jeet Bahadur. 2011. Impacts of Globalization on Quality of Life: Evidence from Developing Countries. Tokyo: Global Institute for Asian Regional Integration.

Self, Sharmistha, and Richard Grabowski. 2004. Does education at all levels cause growth? India, a case study. Economics of Education Review 23: 47-55. [CrossRef]

Sinn, Hans-Werner. 1997. The selection principle and market failure in systems competition. Journal of Public Economics 66: 247-74. [CrossRef]

Stark, Oded. 2004. Rethinking the brain drain. World Development 32: 15-22. [CrossRef]

Stasavage, David. 2005. Democracy and education spending in Africa. American Journal of Political science 49: 343-58. [CrossRef]

Tayebi, Seyed Komail, and Sepideh Esfahani Ohadi. 2009. Globalization and Inequality in Different Economic Blocks. Iranian Economic Review 14: 136-51.

Upton, Joanna B., Jennifer Denno Cissé, and Christopher B. Barrett. 2016. Food security as resilience: Reconciling definition and measurement. Agricultural Economics 47: 135-47. [CrossRef]

Wamala, Sarah, and Ichiro Kawachi. 2007. Globalization and women's health. In Globalization and Health. New York: Oxford University Press, pp. 171-73.

Welander, Anna, Carl Hampus Lyttkens, and Therese Nilsson. 2015. Globalization, democracy, and child health in developing countries. Social Science \& Medicine 136: 52-63.

World Bank. 2016. World Development Indicators. Edited by The World Bank. Washington: World Bank.

World Bank. 2017. Annual World Bank's Report on Ending Extreme. Washington: World Bank.

Yach, Derek, Heather Wipfli, Ross Hammond, and Stanton Glantz. 2007. Globalization and tobacco. Globalization and Health 48: 39-67.

Young, Andrew, Daniel Levy, and Matthew Higgins. 2004. Many Types of Human Capital and Many Roles in US Growth: Evidence from County-Level Educational Attainment Data. Public Economics 0403002. Munich: University Library of Munich.

(C) 2019 by the authors. Licensee MDPI, Basel, Switzerland. This article is an open access article distributed under the terms and conditions of the Creative Commons Attribution (CC BY) license (http://creativecommons.org/licenses/by/4.0/). 